\title{
Biomarker development in MET-targeted therapy
}

\author{
Yanni Zhang ${ }^{1}$, Zhiqiang Du$^{1}$ and Mingqiang Zhang ${ }^{1}$ \\ ${ }^{1}$ Amgen Biopharmaceutical Research and Development (Shanghai) Co., Ltd, Shanghai, China \\ Correspondence to: Mingqiang Zhang, email: mzhang01@amgen.com \\ Keywords: MET, amplification, overexpression, biomarker, MET-targeted therapy \\ Received: September 18, $2015 \quad$ Accepted: March 14, 2016 \\ Published: March 22, 2016
}

\section{ABSTRACT}

\begin{abstract}
Activation of the MET receptor tyrosine kinase by its ligand, hepatocyte growth factor (HGF), has been implicated in a variety of cellular processes, including cell proliferation, survival, migration, motility and invasion, all of which may be enhanced in human cancers. Aberrantly activated MET/HGF signaling correlates with tumorigenesis and metastasis, and is regarded as a robust target for the development of novel anti-cancer treatments. Various clinical trials were conducted to evaluate the safety and efficacy of selective HGF/MET inhibitors in cancer patients. There is currently no optimal or standardized method for accurate and reliable assessment of MET levels, or other biomarkers that are predictive of the patient response to METtargeted therapeutics. In this review, we discuss the importance of accurate HGF/ MET signal detection as a predictive biomarker to guide patient selection for clinical trials of MET-targeted therapies in human cancers.
\end{abstract}

\section{INTRODUCTION}

Receptor tyrosine kinases (RTKs) are involved in many vital processes including mammalian development, cell function and tissue homeostasis. The RTK MET and its ligand hepatocyte growth factor (HGF) activate multiple signaling pathways mediating embryogenesis, tissue regeneration and wound repair under normal physiological conditions [1]. However, an aberrant MET/ HGF axis results in cell migration and survival and promotes tumor development and progression [2-4].

The MET proto-oncogene, located on chromosome 7 (7q21-31), is widely expressed in the epithelial cells of organs such as the liver, lung, gastrointestinal tract, and kidney during embryogenesis and adulthood [5]. HGF binding to the extracellular domain of MET results in its homodimerization and autophosphorylation at multiple tyrosine residues, including Y1234 and Y1235 in the kinase domain and subsequently Y1349 and Y1356 in the carboxy-terminal tail $[6,7]$. Tyrosine phosphorylation of MET results in its activation and recruitment of signaling effectors, including adaptor proteins Grb2, Gab-1, Src and SHC, and subsequent phosphorylation of downstream transducers such as PI3K, ERK, PLC- $\gamma$, FAK and STAT3 [8]. HGF-induced MET activation can trigger cell proliferation, survival, motility, invasion, angiogenesis and branching morphogenesis [9-11].

Gab-1 binding to MET through GRB2 primarily leads to activation of the phosphoinositide 3-kinase $(\mathrm{PI} 3 \mathrm{~K}) / \mathrm{Akt}$ and mitogen-activated protein kinase (MAPK)/ERK pathways. In the MAPK cascade, MET activation stimulates SHC and GRB2 recruitment to Gab-1, leading to MAPK activation [12], along with recruitment of SHP2 to Gab-1 that can link MET signaling to the MAPK cascade and extend the duration of MAPK phosphorylation [13]. The ERK-MAPK pathway is responsible for cell proliferation, cell-cycle progression and cell motility. The p85 subunit of PI3K can bind to MET directly and signal through the AKT pathway, stimulating cell survival [14]. Additional pathways responsible for cell migration and invasion response to MET signaling including RAS, CRK, and focal adhesion kinase (FAK) signaling [15]. STAT3 activation and nuclear translocation following MET binding is associated with tissue invasion [16]. MET ubiquitination by E3-ubiquitin ligase $\mathrm{c}-\mathrm{Cbl}$ leads to MET degradation and is critical for controlled regulation of MET activity [17].

Interactive crosstalk between MET and other cell membrane proteins has been heavily investigated due to the development of drug resistance in targeted therapies. For example, the adhesion protein CD44 variant (CD44v6) is thought to promote downstream activation of the Ras pathway by complex formation between GRB2 and ezrin, radixin and moesin [18]. MET can bind integrin $\alpha 6 \beta 4$ in the presence of HGF, resulting in integrin phosphorylation and cell invasion. MET can be transactivated by directly 
binding epidermal growth factor receptor (EGFR) in the absence of HGF and presence of EGF or TGF- $\alpha$ [19]. Interactions between MET and other RTKs, including RON, PDGFR, Axl, HER2, ERBB3 and VEGFR family members, have been observed in a variety of cancers $[20$, $21]$.

\section{Aberrant MET activation in cancer}

Aberrant HGF/MET axis activation has been implicated in the progression of multiple human tumor types, including liver, lung and gastric carcinomas [22, 23 ], and results in cell survival and migration and tumor development and progression [2-4]. HGF/MET signaling pathway activation can occur via MET gene amplification [24], overexpression [25], mutations [26-28] or paracrine and autocrine activation of MET by HGF [29], all of which have been observed in multiple human tumor types $[22,23]$.

MET overexpression has been reported in many human cancers, such as hepatocellular carcinoma (HCC) and non-small cell lung cancer (NSCLC), and correlates with poor prognosis. MET overexpression can occur via: 1) other tumor growth factors, such as EGF and interleukin-1 [25]; 2) transcription regulation by HIF$1 \alpha$ caused by hypoxia in the growing tumor [30]; 3) deregulation by transcription factors Ets and Sp1; or 4) downregulation of microRNAs targeting MET, such as miR-34 or miR-199a-3p [31-33].

$M E T$ gene amplification resulting in protein overexpression and constitutive activation of the MET receptor has been described in NSCLC, gastric carcinoma and HCC, as well as in preclinical models [24] 'addicted' to the MET signaling pathway. In gastric cancer, MET activation has been attributed to MET gene amplification or overexpression, which reduces apoptosis and promotes tumor cell survival, proliferation, differentiation and migration $[34,35]$.

MET mutations occur only rarely in cancers, but may correlate with tumor development. Constitutively activated MET mutations alter the molecular conformation of the protein structure, either promoting receptor dimerization or modifying catalytic activity [15]. Missense mutations in MET tyrosine kinase domains were recently detected in hereditary papillary renal cell carcinoma (RCC) [26], childhood HCC [27] and other cancers, and these residues were speculated to inhibit MET enzymatic activity. Somatic mutations have been observed in the MET juxtamembrane domain, deleting the exon responsible for E3-ubquitin protein ligase $\mathrm{Cbl}$ recruitment and reducing MET degradation [28]. Additional mutations have been identified in the MET sema domain in lung cancer, and are associated with HGF binding and receptor dimerization.

\section{MET AS A PREDICTIVE CANCER BIOMARKER}

MET status in patients may serve as a potential biomarker for disease prognosis and a predictor of response to $\mathrm{HGF} / \mathrm{MET}$ inhibitors in the clinic. Tables 1, 2 and 3 summarize $M E T$ gene and protein expression patterns reported from different platforms in gastric, lung and liver carcinomas, respectively. Different reagents and scoring systems that define clinical MET positivity, and correlations between MET status and patient prognosis or outcome are discussed.

\section{Prevalence of $M E T$ gene amplification in cancers}

MET gene amplifications that result in protein overexpression and constitutive activation of the MET receptor kinase have been reported in NSCLC, gastric cancers and HCC [24]. Variable MET gene amplification rates were detected depending on the detection method (e.g., fluorescence in situ hybridization [FISH], singlenucleotide polymorphism [SNP] genotyping and quantitative polymerase chain reaction [qPCR]) and the different scoring criteria that define high amplification. In gastric cancer, $M E T$ gene amplification prevalence varies from 2 to $23 \%$ among studies limited by small sample sizes. In one study, a Southern blot using a [a-32P] dCTP-labeled MET-H probe (Oncor, Inc., Gaithersburg, MD, USA) detected MET amplification in $10 \%$ of chemotherapy-naïve primary gastric carcinomas compared with the surrounding normal mucosa [36]. In another study, $21.2 \%$ of formalin-fixed, paraffinembedded (FFPE) primary tumor tissues exhibited MET amplification defined as copy number $>4$ by qPCR [37]. MET amplification was detected by FISH in $2 \%$ of patients with gastric cancer; in this case, $M E T$ amplification was defined as a $M E T / C E P 7$ ratio $>2$ [38]. Several studies with large cohorts correlated $M E T$ gene amplification with advanced tumor stage and poor prognosis in gastric cancer patients undergoing surgery with or without chemotherapy [39-41]. By contrast, MET amplification was barely detectable in patients with $\mathrm{HCC}$ who underwent resection: $4.5 \%$ by SNP genotyping array (Illumina), defined as a copy number $\geq 3$, and $2.3 \%$ by FISH (Abbott Molecular), defined as $M E T / C E P 7 \geq 2.0[42,43]$.

In NSCLC patients with wild-type $E G F R, M E T$ amplification rates ranged between $2.4 \%$ and $21 \%$ depending on the detection approach and study criteria (Table 2). MET amplification was observed in just 3.9\% of TKI-treatment-naïve NSCLC patients as measured by FISH $(M E T / C E P 7>2)$, but in $18 \%$ of patients when measured by qPCR (MET CN $\geq 3)$. MET-FISH positivity or increased $M E T$ copy number predicted worse survival [44, 45]. In TKI-resistant NSCLC patients, MET is amplified at a higher rate, from 15 to $22 \%$, based on FISH, qPCR 
Table 1: Molecular alterations of MET/HGF in human gastric cancer.

\begin{tabular}{|c|c|c|c|c|c|}
\hline Alteration & Findings & Population & Technique & Evaluation & Reference \\
\hline Amplification & $\begin{array}{l}15(23 \%) \text { of the } 64 \\
\text { advanced gastric } \\
\text { carcinomas showed } \\
\text { the c-MET gene } \\
\text { amplification }\end{array}$ & Japan & Southern blot & $\begin{array}{l}\text { Amplification of the } c-M E T \text { gene was } \\
\text { defined as 3-fold or more increase } \\
\text { of signal intensities than those of the } \\
\text { corresponding non-neoplastic mucosa } \\
\text { by densitometry tracing }\end{array}$ & $\begin{array}{l}{[95]} \\
\text { Kuniyasu } \\
\text { et al., } 1992\end{array}$ \\
\hline Amplification & $\begin{array}{l}c-M E T \text { amplification in } \\
10 \%(7 / 70) \text { of patients } \\
\text { with primary gastric } \\
\text { cancer }\end{array}$ & Japan & $\begin{array}{l}\text { Slot Blot } \\
\text { Hybridization }\end{array}$ & $\begin{array}{l}\text { Fold amplification of the } c-M E T \text { gene } \\
\text { relative to each normal mucosa }\end{array}$ & $\begin{array}{l}{[36]} \\
\text { Tsugawa } \\
\text { et al., } 1998\end{array}$ \\
\hline Amplification & $\begin{array}{l}\text { MET amplification in } \\
10.2 \% \text { of } 128 \text { primary } \\
\text { gastric carcinoma } \\
\text { patients without } \\
\text { chemotherapy }\end{array}$ & Japan & Southern blot & $\begin{array}{l}\text { Comparing the levels of } M E T \text { gene } \\
\text { in tumor tissue with those in the } \\
\text { respective normal gastric mucosa }\end{array}$ & $\begin{array}{l}{[53]} \\
\text { Nakajima } \\
\text { et al., } 1999\end{array}$ \\
\hline Amplification & $\begin{array}{l}21.2 \% \text { of FFPE primary } \\
\text { tumor tissues from } 472 \\
\text { patients had a } M E T \\
\text { copy number greater } \\
\text { than } 4.0 \text { copies }\end{array}$ & Korea & qPCR & $\begin{array}{l}\text { MET copy number }>4.0 \text { copies defined } \\
\text { as } M E T \text { amplification }\end{array}$ & $\begin{array}{l}{[37] \text { Lee et }} \\
\text { al., } 2011\end{array}$ \\
\hline Amplification & $\begin{array}{l}0 / 38 \text { patients with } \\
\text { locally advanced } \\
\text { gastric cancer }\end{array}$ & US & FISH & $\begin{array}{l}M E T \text { amplification defined as } M E T / \\
C E P 7 \text { ratio }>2\end{array}$ & $\begin{array}{l}{[54]} \\
\text { Janjigian } \\
\text { et al., } 2011\end{array}$ \\
\hline Amplification & $\begin{array}{l}\text { In } 216 \text { assessable } \\
\text { patients, MET CNG } \\
\text { five or more copies } \\
\text { occurred in } 21 \text { patients } \\
(10 \%) \text { with stage II or } \\
\text { III radically resected } \\
\text { gastric cancer }\end{array}$ & Italy & qPCR & $\mathrm{CNG} \geq 5$ copies as $M E T$ positive & $\begin{array}{l}{[96]} \\
\text { Graziano } \\
\text { et al., } 2011\end{array}$ \\
\hline Amplification & $\begin{array}{l}\text { MET amplification in } \\
\text { ten }(2 \%) \text { of } 489 \text { patients } \\
\text { with GEC }\end{array}$ & Boston & FISH & $\begin{array}{l}\text { Gene amplification as a gene-to-CN } \\
\text { control probe ratio G:CN }>2.2 \text { scored } \\
\text { in } 50 \text { tumor nuclei }\end{array}$ & $\begin{array}{l}{[38]} \\
\text { Lennerz et } \\
\text { al., } 2011 \\
\end{array}$ \\
\hline Amplification & $\begin{array}{l}\text { High polysomy of } \\
\text { chromosome } 7 \text { and GA } \\
\text { in } 61(16.0 \%) \text { and } 13 \\
(3.4 \%) \text { of } 381 \text { primary } \\
\text { gastric carcinoma } \\
\text { patients }\end{array}$ & $\begin{array}{l}\text { Seoul, } \\
\text { Korea }\end{array}$ & $\begin{array}{l}\text { 1. SISH } \\
\text { 2. qPCR }\end{array}$ & $\begin{array}{l}\text { 1. Positive SISH: high polysomy }(\geq 4 \\
\text { copies in } \geq 40 \% \text { of cells; GA (defined } \\
\text { by the presence of tight } M E T \text { gene } \\
\text { clusters and a ratio of } M E T \text { gene to- } \\
\text { chromosome of } \geq 2 \text { or } \geq 15 \text { copies of } \\
M E T \text { per cell in } \geq 10 \% \text { of analyzed } \\
\text { cells } \\
2 \text {. Normalized gene ratios were } \\
\text { interpreted as follows: }<2=\text { negative } \\
\text { for GA and } \geq 2.0=\text { positive for GA. All } \\
\text { results were normalized vs respective } \\
\text { amounts of RNaseP DNA (Applied } \\
\text { Biosystems) }\end{array}$ & $\begin{array}{l}{[40] \text { Lee et }} \\
\text { al., } 2012\end{array}$ \\
\hline Amplification & $\begin{array}{l}\text { MET amplification } \\
\text { observed in } 8.3 \% \\
(19 / 230 \text { cases }) \text { with } \\
\text { recurrent/Metastatic } \\
\text { GC after chemotherapy } \\
\end{array}$ & $\begin{array}{l}\text { Guangzhou, } \\
\text { China }\end{array}$ & FISH & $\begin{array}{l}\text { FISH+ (GA): } M E T / C E P 7 \geq 2 \text { or } \geq 15 \\
\text { copies of } M E T \text { per cell in } \geq 10 \% \text { of } \\
\text { analyzed cells }\end{array}$ & $\begin{array}{l}{[39] \text { An et }} \\
\text { al., } 2013\end{array}$ \\
\hline Amplification & $\begin{array}{l}\text { MET amplification in } 4 \\
\text { of } 266 \text { FFPE specimens } \\
(1.5 \%) \text { of advanced } \\
\text { gastric cancer }\end{array}$ & Japan & $\begin{array}{l}\text { 1. qPCR } \\
\text { 2. FISH }\end{array}$ & $\begin{array}{l}\text { 1. CNG }>4 \text { copies as } M E T \text { positive } \\
\text { 2. Gene amplification defined as a } \\
\text { mean } M E T / C E N 7 p \text { copy number ratio } \\
\text { of }>2.2\end{array}$ & $\begin{array}{l}{[97]} \\
\text { Kawakami } \\
\text { et al., } 2013\end{array}$ \\
\hline Amplification & $\begin{array}{l}\text { In } 95 \text { patients with } \\
\text { advanced GC treated } \\
\text { with chemotherapy, } 15 \\
(16 \%) M E T \text { CNG }>=5 \\
\text { copies cases }\end{array}$ & Italy & qPCR & $\begin{array}{l}\mathrm{Ct} \text { value for the copy number and } \\
\text { reference assay was imported into } \\
\text { the CopyCaller Software (Applied } \\
\text { Biosystems) for post-PCR data } \\
\text { analysis; } \mathrm{CNG} \geq 5 \text { copies }(M E T+)\end{array}$ & $\begin{array}{l}{[98]} \\
\text { Graziano } \\
\text { et al., } 2014\end{array}$ \\
\hline
\end{tabular}




\begin{tabular}{|c|c|c|c|c|c|}
\hline Amplification & $\begin{array}{l}\text { MET amplifications in } \\
12(6.1 \%) \text { of } 196 \mathrm{GC} \\
\text { patients }\end{array}$ & $\begin{array}{l}\text { Shanghai, } \\
\text { China }\end{array}$ & FISH & $\begin{array}{l}\text { For MET analysis, tumors with } M E T \\
\text { to } C E P 7 \geq 2 \text { or presence of } \geq 10 \% \text { gene } \\
\text { cluster were defined as amplified }\end{array}$ & $\begin{array}{l}\text { [41] Liu et } \\
\text { al., } 2014\end{array}$ \\
\hline Point mutation & \begin{tabular}{|l|} 
Juxtamembrane \\
domain: $1 \% \quad(1 / 85)$ \\
patients with primary \\
gastric cancer
\end{tabular} & Korea & $\begin{array}{l}\text { 1. DHPLC } \\
\text { 2. cold SSCP }\end{array}$ & $\begin{array}{l}\text { gastric carcinoma DNA compared to } \\
\text { normal gastric tissue DNA }\end{array}$ & $\begin{array}{l}\text { [49]Lee et } \\
\text { al., } 2000\end{array}$ \\
\hline Overexpression & $\begin{array}{l}\text { MET overexpression: } \\
46.1 \%(59 / 128 \text { patients } \\
\text { with primary gastric } \\
\text { carcinoma and without } \\
\text { chemotherapy }\end{array}$ & Japan & IHC & $\begin{array}{l}\text { Tumors that were stained positively } \\
\text { for membrane and cytoplasm were } \\
\text { considered to be positive for the } \\
\text { expression of the c-MET. Only } \\
\text { distinct staining in more than } 5 \% \text { of } \\
\text { tumor cells was recorded as positive } \\
\text { immunoreactivity }\end{array}$ & $\begin{array}{l}{[53]} \\
\text { Nakajima } \\
\text { et al., } 1999\end{array}$ \\
\hline Overexpression & $\begin{array}{l}\text { In the IHC study, } \\
\text { c-MET overexpression } \\
\text { in }(71.1 \%) \text { 32 of } 45 \\
\text { patients in gastric } \\
\text { carcinoma compared } \\
\text { with matched normal } \\
\text { gastric tissues }\end{array}$ & Taiwan & $\mathrm{IHC}$ & $\begin{array}{l}\text { The tumors were considered as } \\
\text { positive immunreactivities if } \geq 5 \% \\
\text { of neoplastic cells showed distinct } \\
\text { plasma membrane staining }\end{array}$ & $\begin{array}{l}\text { [99]Huang } \\
\text { et al., } 2001\end{array}$ \\
\hline Overexpression & $\begin{array}{l}\text { MET overexpression } \\
\text { in } 63 \% \text { of } 38 \text { patients } \\
\text { with locally advanced } \\
\text { gastric cancer }\end{array}$ & US & IHC & \begin{tabular}{|l|} 
The percentage of positive tumor \\
cells (scale $0 \%-100 \%$ ) with staining \\
intensity from 0 to $3+$. Positive IHC \\
expression is defined as $25 \%$ or more \\
staining with intensity 2 or $3+$
\end{tabular} & $\begin{array}{l}{[54]} \\
\text { Janjigian } \\
\text { et al., } 2011\end{array}$ \\
\hline Overexpression & $\begin{array}{lr}\text { MET } & \text { protein } \\
\text { expression: } & 104 \\
(23.7 \%) \text { of } 438 \text { patients } \\
\text { with primary } & \text { gastric } \\
\text { carcinoma,94 } & (21.5 \%) \\
\text { with IHC } & 2+\text { and } 10 \\
(2.3 \%) \text { cases with IHC } \\
3+\end{array}$ & $\begin{array}{l}\text { Seoul, } \\
\text { Korea }\end{array}$ & IHC & $\begin{array}{l}\text { No membrane staining or membrane } \\
\text { staining in }<10 \% \text { of tumour cells } \\
\text { (score 0), faint/barely perceptible } \\
\text { partial membrane staining in }>10 \% \\
\text { of tumour cells (score 1+), weak- } \\
\text { to-moderate staining of the entire } \\
\text { membrane in }>10 \% \text { of tumour cells } \\
\text { (score } 2+\text { ), and strong staining of the } \\
\text { entire membrane in }>10 \% \text { of tumour } \\
\text { cells (score } 3+\text { ). Scores of } 0 \text { and } 1+ \\
\text { were considered as negative for MET } \\
\text { overexpression, and scores of } 2+\text { and } \\
3+\text { were considered as positive }\end{array}$ & $\begin{array}{l}\text { [40]Lee et } \\
\text { al., } 2012\end{array}$ \\
\hline Overexpression & $\begin{array}{l}\text { MET overexpression } \\
\text { in } 108(21.8 \%) \text { of } 495 \\
\text { patients in advanced } \\
\text { gastric carcinoma }\end{array}$ & Korea & $\mathrm{IHC}$ & $\begin{array}{l}\text { Both membranous and cytoplasmic } \\
\text { staining was scored as follows: } 0 \text {, no } \\
\text { reactivity or faint staining; } 1+\text {, faint or } \\
\text { weak staining; } 2+\text {, moderate staining; } \\
3+\text {, strong staining in }>10 \% \text { of tumor } \\
\text { cells. MET overexpression was } \\
\text { defined as } 2+\text { or } 3+\text { by membranous } \\
\text { and cytoplasmic interpretation }\end{array}$ & $\begin{array}{l}{[55] \mathrm{Ha} \text { et }} \\
\text { al., } 2013\end{array}$ \\
\hline Overexpression & $\begin{array}{l}\text { MET overexpression } \\
(\text { IHC3+) in } 9.6 \% \\
(22 / 229 \text { cases }) \text { with } \\
\text { recurrent/Metastatic } \\
\text { GC after chemotherapy }\end{array}$ & $\begin{array}{l}\text { Guangzhou, } \\
\text { China }\end{array}$ & $\mathrm{IHC}$ & $\begin{array}{l}\text { The staining intensity and percentage } \\
\text { of positive cells were assessed: } \\
3+, \geq 50 \% \text { tumor cells with strong } \\
\text { membrane/cytoplasm staining; 2+, } \\
\geq 50 \% \text { of tumor cells with moderate } \\
\text { membrane/cytoplasm staining; 1+, } \\
\geq 50 \% \text { of tumor cells with weak } \\
\text { membrane/cytoplasm staining; 0, No } \\
\text { staining or } \leq 50 \% \text { of tumor cells with } \\
\text { membrane/cytoplasm staining of any } \\
\text { intensity; }\end{array}$ & $\begin{array}{l}\text { [39]An et } \\
\text { al., } 2013\end{array}$ \\
\hline Overexpression & $\begin{array}{l}\text { MET overexpression } \\
(\text { IHC2+ or } 3+) \text { in } \\
12.3 \%(26 / 212 \text { cases }) \\
\text { of GC patients }\end{array}$ & $\begin{array}{l}\text { Shanghai, } \\
\text { China }\end{array}$ & IHC & $\begin{array}{l}\text { DAKO HercepTest guideline used } \\
\text { to semi-quantitatively score MET } \\
\text { expression. MET+ defined by IHC } 2+/ \\
\text { IHC3+ }\end{array}$ & $\begin{array}{l}\text { [41]Liu et } \\
\text { al., } 2014\end{array}$ \\
\hline
\end{tabular}


and aCGH profiling [46-48]. These findings highlight the need for identification of lung cancer patients with MET amplification who will benefit from combination therapy due to primary or acquired resistance, regardless of their EGFR status.

\section{Prevalence of $M E T$ mutations in cancers}

Although MET mutations happen rarely in cancers, they may correlate with tumor development. Protein structure alterations, either via promotion of receptor dimerization or alteration of catalytic activity, can be attributed to increased kinase activity in MET mutants [15]. Missense mutations were detected in the MET juxtamembrane domain in only $1 \%$ of patients with primary gastric cancer using methods such as denaturing HPLC (DHPLC) (Transgenomics) or cold single-strand conformation polymorphism (SSCP; Novex); these mutations may contribute to tumorigenesis [49]. In NSCLC, somatic mutations in the MET juxtamembrane domain result in the deletion of exon 14, which is responsible for recruitment of the E3-ubquitin ligase, Cbl. This leads to the accumulation of abnormally spliced, activated MET unregulated by Cbl-induced degradation. This mutation was associated with elevated MET expression in primary tumors, which was detected in approximately $3 \%$ of NSCLC patients $[28,50]$. Recently, polymorphisms in the juxtamembrane (R988C and T1010I) and sema (N375S) domains were detected in 1.7 and $4 \%$ of NSCLC patients, respectively, by PCRbased sequencing; however, no associations between MET mutations and clinical and pathological NSCLC features were observed [51, 52]. MET mutation was detected only in the kinase domain in $30 \%$ of childhood HCC cases by the SSCP method [27].

\section{Prevalence of MET overexpression in cancers}

Immunohistochemistry (IHC), reverse transcriptase PCR (RT-PCR), Western blot and enzyme-linked immunosorbent assay (ELISA) analyses have indicated that MET and HGF levels vary in tumors compared with surrounding normal tissues. MET overexpression was detected in vivo in 9.6 to $71 \%$ of human gastric carcinomas based on methodology and tissue type (Table 1). Notably, different antibodies that recognize various MET epitopes and domains have shown different membrane and/or cytoplasmic staining intensities by IHC. For example, $46.1 \%$ of primary gastric carcinoma patients exhibited cell membrane and cytoplasmic staining in $>5 \%$ of tumor cells using a C-28 antibody (Santa Cruz Biotechnology) and the Dako ENVISION system [53]. In another study with the same antibody, $63 \%$ of patients showed positive MET expression defined as $\geq 25 \%$ of tumor cells with staining intensities of $2+$ or $3+$ [54]. MET overexpression in gastric cancer ranged from 9.6 to $23.8 \%$, as defined by IHC staining intensities of 2+ or 3+, via an SP44 rabbit monoclonal antibody from Ventana Medical System. MET IHC 3+ expression was associated with a shorter OS and PFS, and MET gene copy number detected by FISH correlated with MET protein expression detected by IHC in gastric cancer patients [39-41, 55].

The prevalence of HGF or MET in tissues has also been described in NSCLC tumors with wild-type EGFR. Positive intratumoral HGF expression was identified in $57 \%$ of 104 specimens using an anti-HGF antibody (sc7949, Santa Cruz) according to the IHC Allred scoring system, and expression was associated with poor OS [56]. Using the same antibody in a separate study, HGF overexpression, in which $\geq 50 \%$ of tumor cells exhibited positive staining, was identified in $25 \%$ of 88 patients [57]. Western blot analysis also showed high HGF expression in NSCLC compared with normal lung tissue [58, 59]. HGF overexpression has been implicated in acquired resistance to EGFR inhibitors in patients with EGFR-mutant NSCLC [47]. Notably, the overall rate of MET overexpression measured via IHC varied widely from 13.7 to $61 \%$ in published studies based on cohorts of various sizes with different types of diseases and scoring systems (Table 2). Still, MET FISH-positive and IHC-positive patients reportedly have significantly shorter survival than METnegative patients $[57,60]$.

Similarly, MET overexpression ranged from 20 to $100 \%$ in HCCs compared with surrounding normal hepatic tissue (Table 3). Western blot analysis showed MET overexpression in $52 \%$ of 62 HCC patients, which correlated with increased intrahepatic metastases and shorter (5-yr) OS [61]. Biopsy IHC analysis of 86 HCC patients revealed 20\% with MET overexpression [62], whereas in a separate study employing RT-PCR, most (20/24) patients overexpressed MET [63]. Multiple studies reported that serum HGF concentrations detected via ELISA after hepatectomy were higher as compared to normal tissues. Furthermore, HGF levels were correlated with tumor size, node cirrhosis, tumor recurrence or metastases in HCC patients [64].

Multiple studies have demonstrated that MET/HGF is associated with a poor prognosis. A study of $194 \mathrm{HCC}$ patients showed that those with high MET expression with strong staining patterns $(++)$ had significantly shorter 5-year survival than those with low expression with negative staining patterns (-) [65]. Thus, MET may represent a promising target for cancer therapies. MET and HGF alterations are indeed associated with clinical outcome, metastasis, invasion and disease severity in human cancers, and identification of patients with specific alterations may be critical to predict clinical response to targeted therapies. However, based on reported MET gene amplification and overexpression prevalence (Tables 1-3), discrepancies clearly result from the use of different detection methods, the number of patients enrolled in a 
Table 2: Molecular alterations of MET/HGF in human NSCLC.

\begin{tabular}{|c|c|c|c|c|c|}
\hline Alteration & Findings & Population & Technique & Evaluation & Reference \\
\hline Point mutation & $\begin{array}{l}\text { MET a somatic exon } 14 \text { deleting } \\
\text { splice variant in } 3(1.7 \%) \text { of } 178 \\
\text { NSCLC samples }\end{array}$ & Japan & $\begin{array}{l}\text { PCR-based } \\
\text { sequencing }\end{array}$ & $\begin{array}{l}\text { The sequencing of cDNA } \\
\text { from tumor tissues compared } \\
\text { to adjacent normal lung } \\
\text { tissues }\end{array}$ & $\begin{array}{l}{[51] \text { Okuda et }} \\
\text { al., } 2008\end{array}$ \\
\hline Point mutation & $\begin{array}{l}\text { MET mutations in exon } 14 \text { in } \\
4 \% \text { of NSCLC patients }\end{array}$ & Italy & $\begin{array}{l}\text { PCR-based } \\
\text { sequencing }\end{array}$ & $\begin{array}{l}\text { DNA sequence compared } \\
\text { with wild-type nucleotide } \\
\text { sequence }\end{array}$ & $\begin{array}{l}\text { [52]Ludovini } \\
\text { et al., } 2012\end{array}$ \\
\hline Amplification & $\begin{array}{l}\text { MET amplification in } 4 \text { of } 18 \\
(22 \%) E G F R \text { mutant NSCLCs } \\
\text { that had developed resistance to } \\
\text { gefitinib or erlotinib }\end{array}$ & U.S.A & $\begin{array}{l}\text { 1. } \mathrm{qPCR} \\
\text { 2. FISH }\end{array}$ & $\begin{array}{l}\text { 1. relative to a reference, the } \\
\text { Line- } 1 \text { repetitive element: } \\
M E T \text { copy number } \geq 4 \text { (MET } \\
\text { amplification) } \\
\text { 2. Cells were categorized as } \\
(1) \leq 1 \text { copy of } M E T / C E P 7 \\
;(2) \geq 2 \text { copies or } \geq 3 \text { copies } \\
(M E T \text { amplification })\end{array}$ & $\begin{array}{l}{[48]} \\
\text { Engelman et } \\
\text { al., } 2007\end{array}$ \\
\hline Amplification & $\begin{array}{l}M E T \text { was amplified in NSCLCs } \\
\text { from } 9 \text { of } \\
43(21 \%) \text { patients with acquired } \\
\text { TKI resistance but only } 2(3 \%) \\
\text { tumors from } 62 \text { untreated } \\
\text { patients }\end{array}$ & $\begin{array}{l}\text { New York } \\
\text { Taiwan }\end{array}$ & $\begin{array}{l}\text { aCGH } \\
\text { Profiling }\end{array}$ & $\begin{array}{l}\text { Amplification and deletions } \\
\text { were defined as segment } \\
\text { mean } \log 2 \text { ratios of }>1 \text { or } \\
\text { less than }-1\end{array}$ & $\begin{array}{l}{[46] \text { Bean et }} \\
\text { al., } 2007\end{array}$ \\
\hline Amplification & $\begin{array}{l}\text { Among } 213 \text { NSCLC patients, } \\
\text { increased } M E T \text { copy number } \\
\text { identified in } 12 \text { patients }(5.6 \%)\end{array}$ & Japan & qPCR & 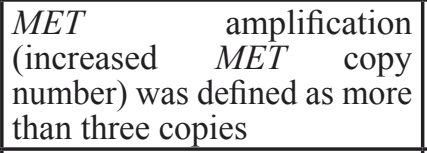 & $\begin{array}{l}{[51] \text { Okuda et }} \\
\text { al., } 2008\end{array}$ \\
\hline Amplification & $\begin{array}{l}M E T \text { amplified in } 22 \text { cases } \\
(21 \%) \text { of } 106 \text { surgically resected } \\
\text { NSCLC patients }\end{array}$ & France & qPCR & $\begin{array}{l}\text { The cut-off value of the } \\
\text { normalized ratio established } \\
\text { for each pair of reference/ } \\
\text { target genes ( B-globine } \\
\text { and GAPDH for MET); } \\
\text { amplified if its normalized } \\
\text { ratio is over M }+2 \text { SD }\end{array}$ & $\begin{array}{l}{[100] \text { Beau- }} \\
\text { Faller et al., } \\
2008\end{array}$ \\
\hline Amplification & $\begin{array}{l}\text { FISH analysis in } 435 \text { primary } \\
\text { NSCLCs. High } M E T \text { gene } \\
\text { copy number (mean } \geq 5 \text { copies/ } \\
\text { cell) was observed in } 48 \text { cases } \\
(M E T+, 11.1 \%) \text { including } 18 \\
\text { cases }(4.1 \%) \text { with true gene } \\
\text { amplification }\end{array}$ & Italy & FISH & $\begin{array}{l}M E T \text { FISH-positive all cases } \\
\text { with mean } \geq 5 \text { copies per cell }\end{array}$ & $\begin{array}{l}{[101]} \\
\text { Cappuzzo et } \\
\text { al., } 2009\end{array}$ \\
\hline Amplification & $\begin{array}{l}\text { In TKI-resistant NSCLC } \\
\text { patients, } c-M E T \text { amplification } \\
\text { in } 17.2 \%(5 / 29)\end{array}$ & China & qPCR & $\begin{array}{l}\text { The cut-off value was } \\
\text { established as the mean } \\
\text { (M)+2 standard deviation } \\
\text { (SD) from normal lung } \\
\text { tissues of } 53 \text { EGFR TKI- } \\
\text { naïve patients. A tumor } \\
\text { sample was defined as } \\
\text { amplification positive if } \\
\text { its ratio value was over } \\
\mathrm{M}+2 \times \text { SD. }\end{array}$ & $\begin{array}{l}{[102] \text { Chen et }} \\
\text { al., } 2009\end{array}$ \\
\hline Amplification & $\begin{array}{l}\text { FISH-positive MET observed } \\
\text { in } 16.7 \% \text {, amplification in } 3.9 \% \\
\text { and high polysomy in } 12.8 \% \text { of } \\
180 \text { resected NSCLCs without } \\
\text { TKI treatment (TKI naÏve) }\end{array}$ & Korea & FISH & $\begin{array}{l}\text { Gene amplification (MET to } \\
C E P 7 \text { ratio } 2 ;>15 \text { copies of } \\
\text { the MET signals in }>10 \% \text { of } \\
\text { tumor cells; high polysomy } \\
\text { ( } \geq 40 \% \text { of cells displaying } \geq 4 \\
\text { copies of the MET signal) }\end{array}$ & $\begin{array}{l}\text { [45]Go et al., } \\
2010\end{array}$ \\
\hline Amplification & $\begin{array}{l}\text { MET amplification in } 8(4 \%) \\
\text { of } 183 \text { patients with lung } \\
\text { adenocarcinoma }\end{array}$ & Japan & qPCR & $\begin{array}{l}\text { Amplification was defined } \\
\text { as a copy number more } \\
\text { than } 1.31 \text { copies, which was } \\
\text { calculated by the mean of } \\
\text { the } M E T \text { gene copy number } \\
\text { measured plus two times of } \\
\text { standard deviation }\end{array}$ & $\begin{array}{l}{[56] \text { Onitsuka }} \\
\text { et al., } 2010 \mathrm{~b}\end{array}$ \\
\hline
\end{tabular}




\begin{tabular}{|c|c|c|c|c|c|}
\hline Amplification & $\begin{array}{l}M E T \text { amplification in } 4 / 27 \\
(15 \%) \text { of TKIs resistant tumor } \\
\text { specimens }\end{array}$ & $\begin{array}{l}\text { Boston, MA } \\
\text { Hong Kong, } \\
\text { China } \\
\text { Guangzhou, } \\
\text { China }\end{array}$ & $\begin{array}{l}\text { 1. } \quad \mathrm{qPCR} \\
\text { 2. FISH }\end{array}$ & $\begin{array}{l}\text { 1. relative to a reference, the } \\
\text { Line- } 1 \text { repetitive element: } \\
\text { MET copy number } \geq 4 \text { (MET } \\
\text { amplification) } \\
\text { 2. Cells were categorized as } \\
\text { (1) } \leq 1 \text { copy of } M E T / C E P 7 \\
;(2) \geq 2 \text { copies or } \geq 3 \text { copies } \\
\text { (MET amplification) }\end{array}$ & $\begin{array}{l}\text { [47]Turke et } \\
\text { al., } 2010\end{array}$ \\
\hline Amplification & $\mid \begin{array}{l}M E T \text { FISH-positive in } \\
11.1 \% \text { of } 380 \text { patients with } \\
\text { surgically resected NSCLC } \\
\text { (high polysomy, 8.7\%; gene } \\
\text { amplification, } 2.4 \% \text { ) }\end{array}$ & Korea & FISH & $\begin{array}{l}\text { High polysomy ( } \geq 4 \text { copies } \\
\text { in } \geq 40 \% \text { of cells); and gene } \\
\text { amplification (presence of } \\
\text { tight gene clusters and a ratio } \\
\text { of } M E T \text { to chromosome } 7 \text { of } \\
\geq 2 \text { or } 15 \geq \text { copies of } M E T \text { per } \\
\text { cell in } \geq 10 \% \text { of cells) }\end{array}$ & $\begin{array}{l}\text { [60]Park et } \\
\text { al., } 2012\end{array}$ \\
\hline Amplification & $\begin{array}{l}\text { Increased MET gene copy } \\
\text { number occurred in } 18.0 \% \text { of } \\
61 \text { NSCLC tissues }\end{array}$ & China & qPCR & $\begin{array}{l}\text { the cut-off was set to } 3 \text { ( } M E T \\
\text { gene copy number } \geq 3 \text { ) }\end{array}$ & $\begin{array}{l}\text { [44]SSun } \\
\text { al., } 2013\end{array}$ \\
\hline Overexpression & $\begin{array}{l}\text { In primary NSCLC carcinomas } \\
\text { from } 42 \text { patients: Western } \\
\text { blot analysis. MET increased } \\
2 \text { to } 10 \text { fold in } 25 \% \text {, HGF } \\
\text { overexpressed } 10-100 \text { fold } \\
\text { compared with adjacent normal } \\
\text { tissue. In IHC, MET/HGF } \\
\text { homogeneous expression in } \\
\text { carcinomas }\end{array}$ & Italy & $\begin{array}{l}\text { 1. Western } \\
\text { blot } \\
\text { 2. IHC }\end{array}$ & $\begin{array}{l}\text { 1. The score relative to } \\
\text { normal lung tissue of the } \\
\text { same patient was as follows: } \\
(-) \text {, negative samples; }(+) \text {, } \\
\text { detectable expression as in } \\
\text { the normal counterpart; }(+ \\
+), 2 \text { - 5-fold and }(+++) \text {, } \\
\text { more than } 10 \text {-fold increase }\end{array}$ & $\begin{array}{l}\text { [58]Olivero } \\
\text { et al., } 1996\end{array}$ \\
\hline Overexpression & $\begin{array}{|lrr|}\text { Western blot analysis. } & \text { MET } \\
\text { overexpression } & \text { in } & 104 \\
\text { patients: 34/47 } & (72 \%) \text { in } \\
\text { adenocarcinomas, } & 20 / 52(38 \%) \\
\text { in squamous cell carcinomas. } \\
\text { IHC in } 104 & \text { patients: } \\
56 / 104 \quad(54 \%) \text { of } & \text { NSCLCs } \\
\text { consisted of } 36 / 47 & (77 \%) \text { of } \\
\text { adenocarcinomas, } & \text { (19/52 (37\%) } \\
\text { of squamous cell carcinomas }\end{array}$ & Japan & $\begin{array}{l}\text { 1. Western } \\
\text { blot } \\
\text { 2. IHC }\end{array}$ & $\begin{array}{l}\text { 1. Band intensity: (-), } \\
\text { undetectable; }(+) \text { slight and } \\
(++) \text { moderate was } 50 \% \\
\text { level of the positive control; } \\
(+++) \text {, stronger than positive } \\
\text { control }\end{array}$ & $\begin{array}{l}{[103]} \\
\text { Ichimura et } \\
\text { al., } 1996\end{array}$ \\
\hline Overexpression & $\begin{array}{l}\text { High HGF expression in } \\
\text { NSCLC }\end{array}$ & $\begin{array}{l}\text { Pittsburgh, } \\
\text { USA }\end{array}$ & $\begin{array}{l}\text { quantitative } \\
\text { Western blot }\end{array}$ & $\begin{array}{l}\text { Bio-Rad assay was used to } \\
\text { measure protein content of } \\
\text { tumor extracts, and results } \\
\text { from Western blots were } \\
\text { expressed as nanograms } \\
\text { of HGF per } 40 \text { ug of tumor } \\
\text { protein }\end{array}$ & $\begin{array}{l}{[59]} \\
\text { Siegfried, } \\
1997\end{array}$ \\
\hline Overexpression & $\begin{array}{l}\text { In patients with small-sized } \\
\text { lung adenocarcinomas, c-MET- } \\
\text { positive in } 69 \text { of } 131 \text { cases } \\
(53 \%)\end{array}$ & Japan & $\mathrm{IHC}$ & $\begin{array}{l}\text { The results were evaluated } \\
\text { as positive when bundles of } \\
\text { myofibroblasts were stained } \\
\text { for c-MET in more than one } \\
\text { microscopic area: occasional } \\
\text { scattered c-MET-positive } \\
\text { cells were considered } \\
\text { negative }\end{array}$ & $\begin{array}{l}{[104]} \\
\text { Tokunou et } \\
\text { al., } 2001\end{array}$ \\
\hline Overexpression & $\begin{array}{l}70 \% \text { of the } 166 \text { primary NSCLC } \\
\text { tissues showed strong HGF } \\
\text { expression }\end{array}$ & Canada & IHC & $\begin{array}{l}\text { Tumors that showed similar } \\
\text { or stronger staining levels } \\
\text { as the normal epithelium } \\
\text { were scored as high HGF } \\
\text { expressors }\end{array}$ & $\begin{array}{l}{[105] \text { TSAO }} \\
\text { et al., } 2001\end{array}$ \\
\hline
\end{tabular}




\begin{tabular}{|c|c|c|c|c|c|}
\hline Overexpression & $\begin{array}{l}\text { In } 88 \text { patients with NSCLCs, } \\
22 \text { carcinomas }(25.0 \%) \text { were } \\
\text { intratumoral HGF-positive, and } \\
36 \text { carcinomas }(40.9 \%) \text { were } \\
\text { intratumoral c-MET positive }\end{array}$ & Japan & IHC & $\begin{array}{l}\text { 1. intratumoral HGF-positive } \\
\text { when } \geq 50 \% \text { of the tumour } \\
\text { cells positively stained for } \\
\text { HGF } \\
2 \text {. Staining intensity } \\
\text { was classified as grade } \\
0 \text { (no staining), grade } 1 \\
\text { (weak staining), grade } \\
2 \text { (moderately strong } \\
\text { staining), grade } 3 \text { (very } \\
\text { strong staining), or grade } 4 \\
\text { (extremely strong staining). } \\
\text { The intratumoral c-MET- } \\
\text { positive when the intensity } \\
\text { of c-MET-stained tumour } \\
\text { cells was greater than grade } \\
1\end{array}$ & $\begin{array}{l}\text { [57]Masuya } \\
\text { et al., } 2004\end{array}$ \\
\hline Overexpression & $\begin{array}{l}\text { MET strongly expressed in } \\
61 \%(14 / 23 \text { cases) of NSCLCs } \\
\text { and p-MET in invasive front of } \\
\text { NSCLC }\end{array}$ & Chicago & IHC & $\begin{array}{l}\text { Immunohistochemical } \\
\text { staining intensity and } \\
\text { extent of c-MET using the } \\
\text { three-scale scoring system: } \\
\text { negative }(0) \text {, weak }(1+) \text {, and } \\
\text { strong }(2+)\end{array}$ & $\begin{array}{l}{[106] \mathrm{Ma} \text { et }} \\
\text { al., } 2005\end{array}$ \\
\hline Overexpression & $\begin{array}{l}\text { In } 130 \text { primary NSCLCs, } \\
\text { phospho-c-MET positive in } \\
21.5 \%(28 / 130) \text { of cases. MET } \\
\text { positive in } 74.6 \% \text { of cases } \\
(97 / 130) \text { and expressed at } \\
\text { high levels in } 36.1 \% \text { of cases } \\
(47 / 130) \text {. HGF at high levels in } \\
31.5 \% \text { of cases }(41 / 130)\end{array}$ & Japan & IHC & $\begin{array}{l}-, \text { complete absence of } \\
\text { staining or only focal } \\
\text { weak staining; } 1+, \text { weak to } \\
\text { moderate staining in less } \\
\text { than } 40 \% \text { of cancer cells; } 2+, \\
\text { weak to moderate staining in } \\
\text { at least } 40 \% \text { of cancer cells; } \\
3+, \text { strong staining in at least } \\
10 \% \text { of cancer cells, among } \\
\text { the specimens with weak to } \\
\text { moderate staining in at least } \\
40 \% \text { of cancer cells. c-MET } \\
\text { low }(- \text { or } 1+) \text { or c-MET high } \\
(2+\text { or } 3+)\end{array}$ & $\begin{array}{l}{[107]} \\
\text { Nakamura et } \\
\text { al., } 2007\end{array}$ \\
\hline Overexpression & $\begin{array}{l}\text { HGF expression was higher in } \\
\text { the TKIs resistant specimens }\end{array}$ & $\begin{array}{l}\text { Boston, MA } \\
\text { Hong Kong, } \\
\text { China } \\
\text { Guangzhou, } \\
\text { China }\end{array}$ & IHC & $\begin{array}{l}\text { The percentage of cancer } \\
\text { cells with positive } \\
\text { cytoplasmic and/or } \\
\text { membranous staining } \\
(0-100 \%) \text {, and the modal } \\
\text { intensity of the positively } \\
\text { staining cells on a scale from } \\
0 \text { to } 4+\text {. The percentage and } \\
\text { the intensity were multiplied } \\
\text { to give a scoring index } \\
\text { ranging from } 0-400\end{array}$ & $\begin{array}{l}\text { [47]Turke et } \\
\text { al., } 2010\end{array}$ \\
\hline Overexpression & $\begin{array}{l}\text { Positive expression of HGF } \\
\text { in } 104 \text { specimens }(57 \%) \text {. } \\
\text { p-MET } 1234 / 1235 \text { in } 12(7 \%) \\
\text { specimens of } 183 \text { patients with } \\
\text { lung adenocarcinoma }\end{array}$ & Japan & IHC & $\begin{array}{l}\text { The score for the positive } \\
\text { staining cells were assigned } \\
\text { according to the frequency } \\
\text { of positive tumor cells }(0, \\
\text { none; } 1,<1 / 100 ; 2,1 / 100 \\
\text { to } 1 / 10 ; 3,1 / 10 \text { to } 1 / 3 ; 4, \\
1 / 3 \text { to } 2 / 3 ; \text { and } 5,>2 / 3) \text {. } \\
\text { Thereafter, } 4 \text { degrees for the } \\
\text { intensity score were assigned } \\
\text { according to the intensity } \\
\text { of the staining }(0, \text { none; } 1, \\
\text { weak; } 2, \text { intermediate; and } 3, \\
\text { strong). The intensity score } \\
\text { were then added to each } \\
\text { other to obtain a total score, } \\
\text { which ranged from } 0 \text { to } 8 . \text { A } \\
\text { positive expression when the } \\
\text { score was } 3 \text { to } 8 \text {. }\end{array}$ & $\begin{array}{l}{[56] \text { Onitsuka }} \\
\text { et al., } 2010 \mathrm{~b}\end{array}$ \\
\hline
\end{tabular}




\begin{tabular}{|c|c|c|c|c|c|}
\hline Overexpression & $\begin{array}{l}\text { MET IHC-positive in } 13.7 \% \\
\text { of } 380 \text { patients with surgically } \\
\text { resected NSCLC }\end{array}$ & Korea & IHC & $\begin{array}{l}\text { The intensity score: } 0=\text { no } \\
\text { appreciable staining in the } \\
\text { tumour cells, } 1=\text { faint } / \text { barely } \\
\text { perceptible partial membrane } \\
\text { staining, } 2=\text { weak to moderate } \\
\text { staining of the entire } \\
\text { membrane, and } 3=\text { strong } \\
\text { staining of the entire } \\
\text { membrane. The fraction } \\
\text { score: } 0=\text { less than } 5 \% \text {, } \\
1=\text { from } 5 \% \text { to } 25 \%, 2=\text { from } \\
26 \% \text { to } 50 \%, 3=\text { from } 51 \% \\
\text { to } 75 \% \text { and } 4=\text { more than } \\
75 \% \text {. The total score was } \\
\text { calculated by multiplying } \\
\text { the intensity score and the } \\
\text { fraction score, producing } \\
\text { a total range of } 0-12 \text {. For } \\
\text { statistical analyses, scores } \\
\text { of } 0-3 \text { were considered } \\
\text { negative, and scores of } 4-12 \\
\text { were considered positive }\end{array}$ & $\begin{array}{l}{[60] \text { Park et }} \\
\text { al., } 2012\end{array}$ \\
\hline Overexpression & $\begin{array}{l}48 \% \text { of samples ( } 83 \text { of } 174) \\
\text { were MET positive. }\end{array}$ & Poland & IHC & $\begin{array}{l}\text { The IHC scoring was done } \\
\text { by one pathologist (B.R.A.) } \\
\text { using the H-score assessment } \\
\text { combining staining intensity } \\
(0-4) \text { and the percentage } \\
\text { of positive cells }(0-100 \%) \text {. } \\
\text { Each individual intensity } \\
\text { level was multiplied by the } \\
\text { percentage of cells, and all } \\
\text { values were added to obtain } \\
\text { the final IHC score, ranging } \\
\text { from } 0 \text { to } 400 \text {. median IHC } \\
\text { score for the population as } \\
\text { the cutoff point }\end{array}$ & $\begin{array}{l}{[108]} \\
\text { Dziadziuszko } \\
\text { et al., } 2012\end{array}$ \\
\hline
\end{tabular}

given study, the use of different scoring systems and differences in cancer types. Standardized and optimized methods are needed to identify robust biomarkers that may assist in the selection of MET-positive patients for future clinical trials of MET-targeted therapies.

\section{BIOMARKER VALIDATION IN MET INHIBITOR CLINICAL TRIALS}

Currently, there is no consensus on the optimal platforms to explore the relationship between MET status and drug efficacies in clinical trials. FISH and IHC assays, both traditional and commercialized approaches, require advanced technical skills and experienced experts or pathologists to analyze results. A validated biomarker detection strategy should be developed to identify a predictive or prognostic factor for these therapies. Here, we summarize the correlation between biomarker validation or clinical inclusion criteria and the therapeutic efficacy of selective MET/HGF kinase inhibitors or antibodies in clinical trials of multiple solid tumors, including GC, NSCLC and HCC.

\section{MET as a therapeutic anti-cancer target}

MET signaling dysregulation in cancer is associated with poor patient outcome. In gastric cancer, MET overexpression or amplification is correlated with tumor stage, metastasis, and shorter overall survival (OS) and progression-free survival (PFS). NSCLC patients may develop resistance to EGFR tyrosine kinase inhibitors (EGFR TKIs) via EGFR T790M mutation, HGF overexpression or $M E T$ amplification/overexpression $[47,48,66]$. Of note, $M E T$ copy number was increased in patients with EGFR TKI-resistant NSCLC compared with TKI-treatment-naïve patients [44-48]. MET activation may compensate for EGFR pathway inhibition via activation of the downstream PI3K pathway, and may correlate with acquired resistance to EGFR TKIs in patients with EGFRmutant NSCLC [47].

MET/HGF has been regarded as a promising therapeutic target in cancer treatment, whose gene or protein status may be indicative of patient response to MET-targeted drugs. Numerous preclinical and clinical studies have demonstrated that antibody or small-molecule inhibitors targeting MET or HGF are effective anti-cancer therapies $[5,22,67]$. 
Table 3: Molecular alterations of MET/HGF in human HCC.

\begin{tabular}{|c|c|c|c|c|c|}
\hline Alteration & Findings & Population & Technique & Evaluation & Reference \\
\hline Amplification & $\begin{array}{l}0 / 125 \text { HCC tumors on } \\
\text { cytoband } 7 \mathrm{q} 31.2\end{array}$ & France & $\begin{array}{l}\text { SNP genotyping } \\
\text { array }\end{array}$ & $\begin{array}{l}\text { 1. Chromosome gain: copy } \\
\text { number of } \geq \text { ploidy }+1 \\
\text { 2. High-level amplification: } \\
\text { copy number of }>\text { ploidy }+2\end{array}$ & $\begin{array}{l}{[109] \text { Guichard }} \\
\text { et al., } 2012\end{array}$ \\
\hline Amplification & $\begin{array}{l}1 / 44(2.3 \%) \text { cases; } 22 / 44 \\
\text { have aneuploidy of } \\
\text { chromosome } 7 \text { in resected } \\
\text { HCC patients }\end{array}$ & Tokyo, Japan & FISH & $\begin{array}{l}\text { 1. } c-M E T / C E P 7=2.0 \text { or } \\
\text { higher (gene amplification) } \\
\text { 2. mean CEP7 signals of } \\
2.5 \text { or higher per nucleus } \\
\text { (chromosome } 7 \text { aneusomies) }\end{array}$ & $\begin{array}{l}{[43] \text { Kondo et }} \\
\text { al., } 2013\end{array}$ \\
\hline Amplification & $\begin{array}{l}\text { High peak frequency } 4.5 \% \\
\text { at cytoband } 7 \mathrm{q} 31.2 \text { in } 286 \\
\text { HCC patients treated with } \\
\text { surgical resection }\end{array}$ & Seoul, Korea & $\begin{array}{l}\text { SNP genotyping } \\
\text { array }\end{array}$ & $\begin{array}{l}\text { Copy numbers } \geq 3 \text { (high- } \\
\text { level amplifications) }\end{array}$ & $\begin{array}{l}{[42] \text { Wang et }} \\
\text { al., } 2013\end{array}$ \\
\hline Point mutation & $\begin{array}{l}\text { Kinase domain: } 30 \% \\
\text { (3/10) childhood HCC } \\
0 / 65 \text { Adult HCC } \\
\end{array}$ & Seoul, Korea & $\begin{array}{l}\text { PCR-based } \\
\text { SSCP }\end{array}$ & $\begin{array}{l}\text { Tumor and corresponding } \\
\text { normal DNA from } \\
\text { each slide were amplified }\end{array}$ & $\begin{array}{l}\text { [27]Park et al., } \\
1999\end{array}$ \\
\hline Point mutation & $\begin{array}{l}0 / 24 \text { patients after surgical } \\
\text { resection }\end{array}$ & France & $\begin{array}{l}\text { Whole-exom } \\
\text { sequencing }\end{array}$ & hg19 reference genome & $\begin{array}{l}{[109] \text { Guichard }} \\
\text { et al., } 2012\end{array}$ \\
\hline Overexpression & $\begin{array}{l}\text { Northern blot analysis. } \\
\text { MET overexpression } \\
\text { in some cases and } \\
\text { underexpression in others. } \\
\text { HGF downregulation } \\
\end{array}$ & $\mathrm{N} / \mathrm{A}$ & Northern blot & $\begin{array}{l}\text { Expression in the tumors } \\
\text { compared to the adjacent } \\
\text { normal liver }\end{array}$ & $\begin{array}{l}{[110] \text { Selden et }} \\
\text { al., } 1994\end{array}$ \\
\hline Overexpression & $\begin{array}{l}\text { Competitive RT-PCR. } \\
\text { Overexpression in some } \\
\text { of the } 11 \text { patients by } \\
\text { surgical resection. HGF } \\
\text { undetectable }\end{array}$ & Japan & $\begin{array}{l}\text { Competitive RT- } \\
\text { PCR }\end{array}$ & $\begin{array}{l}\text { Expression in the } \\
\text { carcinomatous higher than } \\
\text { that in the surrounding non- } \\
\text { cancerous tissues }\end{array}$ & $\begin{array}{l}{[111] \text { Noguchi }} \\
\text { et al., } 1996\end{array}$ \\
\hline Overexpression & $\begin{array}{l}\text { MET overexpression in } \\
\text { all } 20 \mathrm{HCCs} \text { and granular } \\
\text { intracytoplasmic positivity } \\
\text { for HGF in } 9 \text { of } 20 \mathrm{HCCs}\end{array}$ & Italy & $\mathrm{IHC}$ & $\begin{array}{l}\text { The intensity of HGF protein } \\
\text { and c-MET pp plasma- } \\
\text { membrane positivity was } \\
\text { evaluated as weak }(+/++) \text { or } \\
\text { strong }(+++/++++)\end{array}$ & $\begin{array}{l}{[112]} \\
\text { D’ERRICO et } \\
\text { al., } 1996\end{array}$ \\
\hline Overexpression & $\begin{array}{l}\text { Western blot analysis. } \\
52 \% \text { of } 62 \text { patients with } \\
\text { MET overexpression, } \\
\text { correlating with increased } \\
\text { incidence of intrahepatic } \\
\text { Metastases and shorter } \\
5 \text {-yr OS }\end{array}$ & Japan & $\begin{array}{l}\text { 1. Western blot } \\
\text { 2. ELISA }\end{array}$ & $\begin{array}{l}\text { Densitometry analysis by the } \\
\text { median cutoff value }\end{array}$ & $\begin{array}{l}\text { [61]Ueki et al., } \\
1997\end{array}$ \\
\hline Overexpression & $\begin{array}{l}\text { IHC in } 86 \text { patients' } \\
\text { biopsies. } \\
\text { overexpression in } 20 \% \\
\text { compared to surrounding } \\
\text { hepatic tissue and } \\
\text { downregulation in } 32 \% \text {. } \\
\text { HGF overexpression in } \\
33 \% \text { and downregulation } \\
\text { in } 20 \%\end{array}$ & China & $\mathrm{IHC}$ & $\begin{array}{l}\text { Arbitrary units based } \\
\text { on the intensity of the } \\
\text { reaction. 0, no staining; } \\
+, \text { weak reactivity: }++ \\
\text { moderate reactivity: }+++ \text {, } \\
\text { strong reactivity: and }++ \\
++, \text { very strong reactivity, } \\
\text { respectively }\end{array}$ & $\begin{array}{l}\text { [62]Kiss et al., } \\
1997\end{array}$ \\
\hline Overexpression & $\begin{array}{l}\text { MET protein } \\
\text { overexpression in some } \\
\text { cases of human HCC }\end{array}$ & U.S.A & Western blot & $\begin{array}{l}\text { Compared with normal } \\
\text { livers }\end{array}$ & $\begin{array}{l}{[25] \text { Chen }} \\
\text { al., } 1997\end{array}$ \\
\hline Overexpression & $\begin{array}{l}\text { IHC and RT-PCR in } 24 \\
\text { HCC. Overexpression of } \\
\text { MET in most of the cases. } \\
\text { Underexpression of HGF }\end{array}$ & Italy & RT-PCR & $\begin{array}{l}\text { Compared to the surrounding } \\
\text { tissues }\end{array}$ & $\begin{array}{l}\text { [63]Tavian et } \\
\text { al., } 2000\end{array}$ \\
\hline
\end{tabular}




\begin{tabular}{|c|c|c|c|c|c|}
\hline Overexpression & $\begin{array}{l}\text { In } 30 \text { patients with HCC, } \\
\text { MET over-expression } \\
\text { in } 19 \text { cases and under- } \\
\text { expression in } 11 \text { cases. } \\
\text { HGF overexpression } \\
\text { in } 10 \text { cases, and } \\
\text { underexpression in } 20 \\
\text { cases }\end{array}$ & Japan & Western blot & $\begin{array}{l}\text { Each value was obtained } \\
\text { from the comparison with } \\
\text { the level of } \beta \text {-actin, and the } \\
\text { mean values were calculated } \\
\text { from three repeated } \\
\text { measures. Expression level } \\
\text { compared to non-tumor } \\
\text { tissues }\end{array}$ & $\begin{array}{l}{[113] \text { Osada et }} \\
\text { al., } 2005\end{array}$ \\
\hline Overexpression & $\begin{array}{l}\text { Positive } \text { expression } \\
\text { of c-MET protein in } \\
27 \text { cancerous regions } \\
(27 / 31) \text { undergoing } \\
\text { surgical resection. Higher } \\
\text { preoperative concentration } \\
\text { of serum HGF in the liver } \\
\text { cancer patients }\end{array}$ & China & $\begin{array}{l}\text { 1. IHC } \\
\text { 2. ELISA }\end{array}$ & $\begin{array}{l}\text { 1. intensive positive }(+++) \\
\text { when positive cells } \\
\text { comprised more than } 50 \% \\
\text { of the total cells; moderately } \\
\text { positive }(++) \text { when positive } \\
\text { cells comprised } 16-50 \% \text {; } \\
\text { weakly positive }(+) \text { when } \\
\text { positive cells comprised } 10- \\
15 \% \text {; and negative (-) when } \\
\text { positive cells comprised less } \\
\text { than } 10 \% \\
2 \text {. Compared with normal } \\
\text { controls }\end{array}$ & $\begin{array}{l}\text { [64]Wu et al., } \\
2006\end{array}$ \\
\hline Overexpression & $\begin{array}{l}66.6 \% \text { of } 194 \text { HCC } \\
\text { patients with c-MET } \\
\text { positive, 5-yr DFS: } 61.6 \% \\
\text { vs } 22.75 \% \text { (c-MET- vs } \\
\text { c-MET+) }\end{array}$ & China & IHC & $\begin{array}{l}\text { The extent of positive } \\
\text { staining was scored as } \\
\text { follows: 0, } \leq 10 \% ; 1, \\
>10-25 \% ; 2,>25-50 \% ; 3, \\
>50-75 \% ; \text { and } 4,>75 \% \\
\text { The intensity was scored } \\
\text { as follows: 0, negative; 1+, } \\
\text { weak; 2+, moderate; and 3+, } \\
\text { strong. The final score was } \\
\text { obtained by multiplying the } \\
\text { extent scores and intensity } \\
\text { scores, producing a range } \\
\text { from 0 to 12. Scores 9-12 } \\
\text { were defined as strong } \\
\text { staining pattern (++), } \\
\text { scores 0-4 were defined as } \\
\text { negative expression (-), and } \\
\text { scores 6-8 were defined as } \\
\text { intermediate staining pattern } \\
(+)\end{array}$ & $\begin{array}{l}\text { [65]Wang, et } \\
\text { al., } 2008\end{array}$ \\
\hline Overexpression & \begin{tabular}{|lrr} 
C-MET & expression in \\
$87.5 \%$ & HCC & patients \\
undergoing & & hepatic \\
resection. 29 & of & 40 \\
patients & $(73 \%)$ & had \\
increased concentrations \\
of portal HGF
\end{tabular} & Taiwan & $\begin{array}{l}\text { 1. IHC } \\
\text { 2. EISA }\end{array}$ & $\begin{array}{l}\text { 1. Immunoreactivity of } \\
\text { c-MET was classified as } \\
\text { negative when }<10 \% \text { of the } \\
\text { cells stained positively, and } \\
\text { positive when } \geq 10 \% \text { of the } \\
\text { cells stained positively } \\
\text { 2. Posthepatectomy portal } \\
\text { HGF levels compared to } \\
\text { prehepatectomy portal HGF } \\
\text { levels }\end{array}$ & $\begin{array}{l}{[114] \text { Chau et }} \\
\text { al., 2008 }\end{array}$ \\
\hline Overexpression & $\begin{array}{l}\text { In } 520 \text { total patients, } 282 \\
\text { c-MET+ patients }(54.2 \%) \text {, } \\
\text { correlating with shorter } \\
7 \text {-yr OS }\end{array}$ & China & IHC & $\begin{array}{l}\text { Mean area of positive } \\
\text { staining as cutoff value, } \\
\text { c-MET high, }>20 \% \text { of tumor } \\
\text { section }\end{array}$ & $\begin{array}{l}{[115] \mathrm{Ke} \text { et al., }} \\
2009\end{array}$ \\
\hline
\end{tabular}




\begin{tabular}{|c|c|c|c|c|c|}
\hline Overexpression & $\begin{array}{l}\text { 15/59 }(25.4 \%) \text { cases high } \\
\text { level of c-MET expression }\end{array}$ & Tokyo, Japan & IHC & $\begin{array}{l}\text { 4-point scoring system: } 0 \\
=\text { no staining observed in } \\
\text { invasive tumor cells; } 1+= \\
\text { weak, incomplete membrane } \\
\text { staining in any proportion } \\
\text { of the invasive tumor } \\
\text { cells, or weak, complete } \\
\text { circumferential membrane } \\
\text { staining in fewer than } \\
10 \% \text { of cells; } 2+=\text { weak } \\
\text { but complete membrane } \\
\text { staining in at least } 10 \% \text { of } \\
\text { cells, or intense complete } \\
\text { circumferential membrane } \\
\text { staining in } 30 \% \text { or fewer of } \\
\text { tumor cells; } 3+=\text { intense } \\
\text { complete ircumferential } \\
\text { membrane staining in more } \\
\text { than } 30 \% \text { of tumor cells. } \\
\text { scores } 0 \text { and } 1+\text { as c-MET } \\
\text { low, and scores } 2+\text { and } 3+\text { as } \\
\text { c-MET high }\end{array}$ & $\begin{array}{l}{[43] \text { Kondo et }} \\
\text { al., } 2013\end{array}$ \\
\hline Overexpression & $\begin{array}{l}\text { High expression of c-MET } \\
\text { in } 80.6 \% \text { of } 93 \text { HCC } \\
\text { patients. No correlation } \\
\text { with clinicopathological } \\
\text { factors, but correlated } \\
\text { with PFS }\end{array}$ & Italy & IHC & $\begin{array}{l}\text { Combination of positive cell } \\
\text { count and staining intensity } \\
\text { used for scoring. Positive } \\
\text { cell count, } 0-10 \% \text {, score 0; } \\
11-25 \% \text { score } 1 ; 26-50 \% \text {, } \\
\text { score } 2 ; 51-75 \% \text { score } 3 \text {; } \\
>75 \% \text {, score } 4 \text {. Staining } \\
\text { intensity: negative score 0; } \\
\text { faint yellow, score 1; yellow } \\
\text { or deep yellow, score 2; } \\
\text { brown or dark brown, score } \\
\text { 3. High expression, Score } \geq 5\end{array}$ & $\begin{array}{l}{[116] \mathrm{Chu}} \\
\text { al., } 2013\end{array}$ \\
\hline
\end{tabular}

\section{Volitinib}

Volitinib is a highly selective small molecule, ATPcompetitive MET kinase inhibitor being investigated as a monotherapy for $M E T$-amplified cancers, such as gastric and lung cancer. Currently, this drug is in clinical development stage, including phase I studies in Australia and China, to test its efficacy against advanced cancers. Other phase I trials seek to test combinations of volitinib and docetaxel in gastric cancer (NCT02252913) and volitinib and gefitinib for EGFR TKI-resistant NSCLC in patients with mutant EGFR (NCT02374645).

In preclinical studies, biomarker analysis has shown that MET-amplified and MET-overexpressing tumor xenograft models are highly responsive to volitinib as a single agent or in combination with other therapies [6871]. An in vivo study indicated that volitinib selectively inhibited the growth of MET-driven gastric and lung cancer cell line and primary tumor xenografts [68-71]. Anti-tumor efficacy in gastric cancer correlated with MET gene amplification/overexpression and high levels of phosphorylated-MET (p-MET). Additionally, the combination of volitinib and docetaxel demonstrated efficacy in a $M E T$-amplified gastric cancer cell line and in primary xenograft models [69]. However, correlations between tumor growth inhibition and MET status were less clear in lung cancer compared with gastric cancer. This may be the result of heterogeneity or variation in p-MET or the activation of compensatory pathways (e.g., EGFR, KRAS) in lung cancer [71]. In particular, the combination of volitinib and taxotere had satisfactory efficacy in tumors less responsive to volitinib monotherapy [71]. The in vivo efficacy of volitinib was tested in a model of EGFR TKI-resistant NSCLC (HCC872C4R) with acquired MET gene amplification. Volitinib with gefitinib produced a synergistic effect compared with volitinib monotherapy, which produced a poor dose response [70]. Therefore, volitinib selectively inhibited tumor growth in a series of human tumor xenograft models with aberrant MET signaling.

MET-FISH was applied to an assessment of MET amplification that involved labeling bacterial artificial chromosome (BAC) DNA with Spectrum Red (ENZO) and CEP7-Spectrum Green probe (Vysis Abbott). MET amplification was defined as a $M E T / C E P 7$ ratio $\geq 2$ or cluster signals in $>10 \%$ of tumor cells. MET-IHC (SP44 Ventana Medical System, Roche) was used to detect MET overexpression, which was defined as a staining intensity of $2+$ or $3+(\geq 10 \%$ of tumor cells with membrane or cytoplasmic staining of moderate or strong intensity). MET-FISH or MET-IHC positivity was considered a 
predictive marker for response to therapy and determined the patient selection criteria. Volitinib demonstrated robust in vivo anti-tumor effects on predominantly MET-driven gastric and lung cancers in which the MET gene was amplified, while volitinib combined with chemotherapy could produce additional benefits in the treatment of tumors in which MET was a partial driver and where patients exhibited poor responses to volitinib monotherapy [68-71]. In an early clinical evaluation, a volitinib doseescalation study was performed to evaluate the drug's efficacy against advanced solid tumors, including gastric and lung cancers [72]. In 29 of 35 evaluable patients treated with $100-1000 \mathrm{mg}$ volitinib daily or $300-400 \mathrm{mg}$ twice daily for 21 days, $10 \%$ exhibited partial responses (PR), and 59\% exhibited stable disease (SD) in at least one post-treatment. Anti-tumor volitinib activities were observed primarily in patients with papillary renal cell carcinoma (PRCC). Furthermore, data suggested that $M E T$ gene copy number gain could be a biomarker for therapeutic response. The correlation between MET status and clinical efficacy will be further investigated to improve the patient selection criteria for later-stage clinical trials.

\section{INC280}

INC280 (Novartis) is a potent and highly selective MET kinase inhibitor currently being evaluated in earlystage clinical studies. INC280 inhibited cell proliferation, migration and apoptosis in MET-driven tumor cell lines. INC280 suppressed tumor growth in vivo in a dosedependent manner, and was extremely well tolerated, especially in mouse xenograft models of MET-driven glioblastoma and gastric cancer $[73,74]$.

A phase I clinical study reported stable disease in $24 \%(8 / 33)$ of patients with MET-driven advanced solid tumors, including PRCC, NSCLC, HCC, gastric cancer and others (NCT01324479). INC280 showed preliminary anti-tumor efficacy as a single agent in $50 \%$ of patients with $E G F R$ wild-type NSCLC with MET dysregulation, as confirmed by FISH (MET/centromere ratio $\geq 2.0$ or $M E T$ gene copy number $\geq 5$ ) or IHC (MET H-score $\geq 150$ or $50 \%$ of tumor cells with a staining intensity of $2+$ or $3+$ ) [75].

In MET-positive NSCLC tumors with mutant EGFR that were found resistant to EGFR TKIs, a phase Ib/II study of INC280 in combination with gefitinib reported partial responses in $8 / 46(17 \%)$ of evaluable patients with high MET status (IHC 3+ and/or MET copy number via FISH $\geq 5$ ) (NCT01610336). Overall response rates were $40 \%$ in patients with $M E T C N \geq 5$ and $38 \%$ in patients with MET IHC staining intensity of 3+ [76]. Unexpectedly, some NSCLCs with high MET expression (IHC 3+) and amplification exhibited tumor progression following treatment. Whether the platform, reagents and scoring system were appropriate for MET status assessment should be further evaluated in a phase II expansion study.
A phase I study of INC280 plus erlotinib in patients with MET-expressing NSCLC (NCT01911507) is ongoing. In $\mathrm{HCC}$, a phase II clinical trial of INC280 as a first-line treatment is currently recruiting patients with tumors that harbor with activated MET pathways (NCT01737827).

\section{Rilotumumab}

Rilotumumab (previously known as AMG 102; Amgen) is a fully human monoclonal HGF antibody that preferentially binds to the mature, active form of the protein [77]. Interaction with rilotumumab prevents HGF from binding to MET, which prevents subsequent signaling [78]. The antibody was tested in preclinical models and in clinical trials in multiple solid tumors, either as a monotherapy or in combination with other chemotherapeutics [79-83]. Based on preclinical data, rilotumumab has shown the anti-tumor activity in vitro and in vivo studies, [79, 84]. In a phase I clinical trial, rilotumumab monotherapy was deemed safe and well tolerated in 40 patients with refractory advanced solid tumors. A total of 16/23 (70\%) evaluable patients achieved stable disease as a best response with PFS from 7.9 to 40 weeks [81].

In a phase II trial (NTC00719550), rilotumumab in combination with the cytotoxic agents epirubicin, cisplatin or capecitabine (ECX) was evaluated in 121 patients with advanced or metastatic gastric or esophageal junction $(\mathrm{G} /$ EGJ) cancer. Rilotumumab plus ECX had an anti-tumor efficacy compared to ECX alone, with modestly improved OS (median months, 10.6 vs. 8.9; hazard ratio [HR] = 0.70) and PFS (median months, 5.7 vs. 4.2; HR =0.60) [85]. The MET-positive tumors were defined as such when at least $25 \%$ of tumor cells demonstrated membrane staining at any intensity using the MET4 monoclonal antibody and the verified MET immunohistochemistry pharmDx kit (Dako North America, Carpinteria, CA, USA). However, rilotumumab plus ECX significantly improved OS in patients with high MET expression compared with ECX alone (10.6 months [95\% CI 8.0-13.4] vs. 5.7 months [4.210.4]). Conversely, MET-negative patients had slightly reduced OS when treated with rilotumumab plus ECX compared with ECX alone (11.1 months [6.9-13.2] vs. 11.5 months [5.5-20.5]). A similar trend was observed for PFS [85].

A phase III study to assess the efficacy and safety of rilotumumab in advanced gastric cancer did not confirm the phase II findings and was terminated due to futility results and casualties with an increased number of deaths as compared to chemotherapy [86]. Rilotumumab arm was not superior to placebo arm for OS (median months, 9.6 vs. 11.5; HR = 1.37) and PFS (median months, 5.7 vs. 5.7; $\mathrm{HR}=1.30)$. OS, PFS and ORR were statistically worse in the rilotumumab arm. Significantly more patients in the placebo arm achieved 12-month OS (49.7\% vs. 38.4\%; $P$ $=0.053)$ and ORR (39.2\% vs. 30\%; $P=0.027)$ compared 
to the rilotumumab arm. No benefit from treatment with rilotumumab was observed, including patients with higher MET expression, and a higher incidence of fetal adverse events occurred in the rilotumumab arm [86]. We suggest that defining MET positivity as IHC staining in $25 \%$ of tumor cells is not stringent enough to establish true MET overexpression, and could lead to negative results in clinical trials. Additionally, rilotumumab was recently reported to be only a partial, not full, HGF antagonist, resulting in HGF-induced MET phosphorylation. This may at least partially explain the poor responses and deaths in rilotumumab clinical trials, and has considerable implications for the use of this therapeutic antibody [87].

\section{Onartuzumab}

Onartuzumab (MetMAb; Roche/Genentech) is a single-armed humanized modified 5D5 anti-MET antibody that binds to the MET sema domain and effectively prevents HGF from binding to MET [88]. Preclinical studies have demonstrated inhibitory effects on glioblastoma U87 and pancreatic BxPC3 and KP4 tumor xenografts, including reduced cell proliferation and motility $[88,89]$. In a phase I study, a complete response was observed in a patient with chemotherapy-refractory metastatic gastric cancer with high MET gene polysomy, high MET expression and evidence of autocrine HGF production [90]. In a randomized, double-blind phase II trial in EGFR-unselected NSCLC patients, no increased benefit in PFS $(\mathrm{HR}=1.09, p=0.69)$ or $\mathrm{OS}(\mathrm{HR}=0.80, p$ $=0.34$ ) was noted in patients receiving onartuzumab plus erlotinib vs. placebo plus erlotinib. However, in METpositive ( $\geq 50 \%$ of tumor cells with a staining intensity of $2+$ or $3+$ ) NSCLC patients (52\% of 137 individuals), onartuzumab plus erlotinib was associated with improved PFS (1.5 vs. 2.9 months, $\mathrm{HR}=0.53, p=0.04$ ) and OS (3.8 vs. 12.6 months, $\mathrm{HR}=0.37, p=0.002$ ). In contrast, MET-negative patients demonstrated worse OS after treatment with onartuzumab compared with patients treated with erlotinib alone. Despite improved PFS and OS in the MET-positive population, the ORR in this subset was not different from that of the placebo plus erlotinib arm [91], possibly because the inclusion criteria for METpositive patients may not have been properly defined. A randomized phase III trial in patients with MET-positive advanced NSCLC who were to receive the standard chemotherapy has been terminated because treatment with onartuzumab in combination with erlotinib did not demonstrate a significant difference over erlotinib alone [92].

\section{CONCLUSIONS}

Because MET is involved in the regulation of tumor cell survival and metastasis, a better understanding of individual patient sensitivities to MET inhibitors can help guide clinical trial design. Therefore, the key to success for MET-targeted therapies in human cancers may lie in MET-driven patient selection, which is determined by many factors.

First, an integrated platform that incorporates accurate, validated methods and reagent kits, such as antibodies and substrates for the characterization of MET alterations, will help to improve MET-driven population selection. For example, a phase III trial of onartuzumab showed a lack of efficacy in patients with advanced NSCLC, who were selected for the trial based on MET overexpression detected via IHC [91]. However, the IHC detection antibody, SP44, binds the cytoplasmic MET domain, whereas onartuzumab binds to the extracellular semaphorin domain. Reported IHC results vary widely because different antibodies that target distinct MET epitopes are used. It is critical to utilize specific antibodies for the detection of MET expression as a predictive biomarker to refine patient selection in clinical trials.

Next, MET-positive patient selection must also take into consideration of tumor stage and type, along with sample storage conditions, and must incorporate stringent clinical inclusion criteria. A single biomarker or a combination of biomarkers may serve as prognostic factors to fully inform patient selection. For example, in the phase III onartuzumab clinical trial, defining IHC MET positivity as $50 \%$ of tumor cells with moderate staining intensity might have resulted in the inclusion of patients with false-positive MET-overexpressing tumors.

In a phase II trial, however, IHC analysis correlated better with significant improvements in OS and PFS compared with FISH analysis. In this study, a MET/CEP7 ratio of two or more or a mean of $\geq 5 M E T$ copies per cell were defined as MET FISH positivity, which may result in the inclusion of patients with no $M E T$-amplified tumors [93]. These criteria could explain why NSCLC patients with MET FISH positivity exhibited negative responses to onartuzumab in a phase III trial [92]. Additionally, in rilotumumab studies, defining MET-positive tumors as those having at least $25 \%$ of tumor cells with membrane staining at any intensity may also have resulted in a high rate of false positives. These results together strongly suggest that testing for MET levels should include both MET overexpression assessment by IHC and MET gene amplification analysis by FISH for improved accuracy and reduced false positive detection rates.

Additionally, MET-driven or MET-positive cancer should be determined by the dominant activation of MET and related oncogenic pathways. MET signaling rarely occurs independently. Other oncogenic pathways, such as EGFR and TGF- $\beta$, appear to be involved in tumor progression independent of MET signaling [35]. However, EGFR can also bind with MET and PDGFR, thereby constituting a diversified signal transduction network in cancer cells [94]. In many cancer cases, a combined 
treatment approach that targets both MET and other functionally redundant RTKs should also be considered.

Thus far, no MET inhibitors or antibodies have been approved for clinical use. Evidence is mounting that fighting MET-driven cancers may depend on many elements, such as the specific drug target, disease stage or type, optimal methods for tumor MET status assessment, and, perhaps most importantly, the identification of robust biomarkers as predictors of patient benefit from METtargeting therapeutics.

\section{CONFLICTS OF INTEREST} interest.

The authors declare that they have no conflicts of

\section{REFERENCES}

1. Trusolino L, Bertotti A, Comoglio PM. MET signalling: principles and functions in development, organ regeneration and cancer. Nat Rev Mol Cell Biol. 2010; 11: 834-848.

2. Gonzatti-Haces M, Seth A, Park M, Copeland T, Oroszlan S, Vande Woude GF. Characterization of the TPR-MET oncogene p65 and the MET protooncogene p140 proteintyrosine kinases. Proc Natl Acad Sci U S A. 1988; 85: 2125.

3. Uehara Y, Minowa O, Mori C, Shiota K, Kuno J, Noda T, Kitamura N. Placental defect and embryonic lethality in mice lacking hepatocyte growth factor/scatter factor. Nature. 1995; 373: 702-705.

4. Sonnenberg E, Meyer D, Weidner KM, Birchmeier C. Scatter factor/hepatocyte growth factor and its receptor, the c-met tyrosine kinase, can mediate a signal exchange between mesenchyme and epithelia during mouse development. J Cell Biol. 1993; 123: 223-235.

5. Comoglio PM, Giordano S, Trusolino L. Drug development of MET inhibitors: targeting oncogene addiction and expedience. Nat Rev Drug Discov. 2008; 7: 504-516.

6. Rodrigues GA, Park M. Autophosphorylation modulates the kinase activity and oncogenic potential of the Met receptor tyrosine kinase. Oncogene. 1994; 9: 2019-2027.

7. Ponzetto C, Bardelli A, Zhen Z, Maina F, dalla Zonca P, Giordano S, Graziani A, Panayotou G, Comoglio PM. A multifunctional docking site mediates signaling and transformation by the hepatocyte growth factor/scatter factor receptor family. Cell. 1994; 77: 261-271.

8. Furge KA, Zhang YW, Vande Woude GF. Met receptor tyrosine kinase: enhanced signaling through adapter proteins. Oncogene. 2000; 19: 5582-5589.

9. Sierra JR, Corso S, Caione L, Cepero V, Conrotto P, Cignetti A, Piacibello W, Kumanogoh A, Kikutani H, Comoglio PM, Tamagnone L, Giordano S. Tumor angiogenesis and progression are enhanced by Sema4D produced by tumor-associated macrophages. J Exp Med.
2008; 205: 1673-1685.

10. Conrotto P, Valdembri D, Corso S, Serini G, Tamagnone L, Comoglio PM, Bussolino F, Giordano S. Sema4D induces angiogenesis through Met recruitment by Plexin B1. Blood. 2005; 105: 4321-4329.

11. Yi S, Tsao MS. Activation of hepatocyte growth factor-met autocrine loop enhances tumorigenicity in a human lung adenocarcinoma cell line. Neoplasia. 2000; 2: 226-234.

12. Graziani A, Gramaglia D, dalla Zonca P, Comoglio PM. Hepatocyte growth factor/scatter factor stimulates the Rasguanine nucleotide exchanger. J Biol Chem. 1993; 268: 9165-9168.

13. Maroun CR, Naujokas MA, Park M. Membrane targeting of Grb2-associated binder-1 (Gab1) scaffolding protein through Src myristoylation sequence substitutes for Gab1 pleckstrin homology domain and switches an epidermal growth factor response to an invasive morphogenic program. Mol Biol Cell. 2003; 14: 1691-1708.

14. Xiao GH, Jeffers M, Bellacosa A, Mitsuuchi Y, Vande Woude GF, Testa JR. Anti-apoptotic signaling by hepatocyte growth factor/Met via the phosphatidylinositol 3-kinase/Akt and mitogen-activated protein kinase pathways. Proc Natl Acad Sci U S A. 2001; 98: 247-252.

15. Organ SL, Tsao MS. An overview of the c-MET signaling pathway. Ther Adv Med Oncol. 2011; 3: S7-S19.

16. Syed ZA, Yin W, Hughes K, Gill JN, Shi R, Clifford JL. HGF/c-met/Stat3 signaling during skin tumor cell invasion: indications for a positive feedback loop. BMC Cancer. 2011; 11: 180 .

17. Peschard P, Park M. Escape from Cbl-mediated downregulation: a recurrent theme for oncogenic deregulation of receptor tyrosine kinases. Cancer Cell. 2003; 3: 519-523.

18. Orian-Rousseau V, Morrison H, Matzke A, Kastilan T, Pace G, Herrlich P, Ponta H. Hepatocyte growth factorinduced Ras activation requires ERM proteins linked to both CD44v6 and F-actin. Mol Biol Cell. 2007; 18: 76-83.

19. Puri N, Salgia R. Synergism of EGFR and c-Met pathways, cross-talk and inhibition, in non-small cell lung cancer. J Carcinog. 2008; 7: 9.

20. Follenzi A, Bakovic S, Gual P, Stella MC, Longati P, Comoglio PM. Cross-talk between the proto-oncogenes Met and Ron. Oncogene. 2000; 19: 3041-3049.

21. Yeh CY, Shin SM, Yeh HH, Wu TJ, Shin JW, Chang TY, Raghavaraju G, Lee CT, Chiang JH, Tseng VS, Lee YC, Shen $\mathrm{CH}$, Chow $\mathrm{NH}$ et al. Transcriptional activation of the Axl and PDGFR-alpha by c-Met through a ras- and Srcindependent mechanism in human bladder cancer. BMC Cancer. 2011; 11: 139.

22. Birchmeier C, Birchmeier W, Gherardi E, Vande Woude GF. Met, metastasis, motility and more. Nat Rev Mol Cell Biol. 2003; 4: 915-925.

23. Maulik G, Shrikhande A, Kijima T, Ma PC, Morrison PT, Salgia R. Role of the hepatocyte growth factor receptor, 
c-Met, in oncogenesis and potential for therapeutic inhibition. Cytokine Growth Factor Rev. 2002; 13: 41-59.

24. Smolen GA, Sordella R, Muir B, Mohapatra G, Barmettler A, Archibald H, Kim WJ, Okimoto RA, Bell DW, Sgroi DC, Christensen JG, Settleman J, Haber DA. Amplification of MET may identify a subset of cancers with extreme sensitivity to the selective tyrosine kinase inhibitor PHA665752. Proc Natl Acad Sci U S A. 2006; 103: 2316-2321.

25. Chen Q, Seol DW, Carr B, Zarnegar R. Co-expression and regulation of Met and Ron proto-oncogenes in human hepatocellular carcinoma tissues and cell lines. Hepatology. 1997; 26: 59-66.

26. Lubensky IA, Schmidt L, Zhuang Z, Weirich G, Pack S, Zambrano N, Walther MM, Choyke P, Linehan WM, Zbar B. Hereditary and sporadic papillary renal carcinomas with c-met mutations share a distinct morphological phenotype. Am J Pathol. 1999; 155: 517-526.

27. Park WS, Dong SM, Kim SY, Na EY, Shin MS, Pi JH, Kim BJ, Bae JH, Hong YK, Lee KS, Lee SH, Yoo NJ, Jang JJ et al. Somatic mutations in the kinase domain of the Met/hepatocyte growth factor receptor gene in childhood hepatocellular carcinomas. Cancer Res. 1999; 59: 307-310.

28. Kong-Beltran M, Seshagiri S, Zha J, Zhu W, Bhawe K, Mendoza N, Holcomb T, Pujara K, Stinson J, Fu L, Severin C, Rangell L, Schwall R et al. Somatic mutations lead to an oncogenic deletion of met in lung cancer. Cancer Res. 2006; 66: 283-289.

29. Kentsis A, Reed C, Rice KL, Sanda T, Rodig SJ, Tholouli E, Christie A, Valk PJ, Delwel R, Ngo V, Kutok JL, Dahlberg SE, Moreau LA et al. Autocrine activation of the MET receptor tyrosine kinase in acute myeloid leukemia. Nat Med. 2012; 18: 1118-1122.

30. Pennacchietti S, Michieli P, Galluzzo M, Mazzone M, Giordano S, Comoglio PM. Hypoxia promotes invasive growth by transcriptional activation of the met protooncogene. Cancer Cell. 2003; 3: 347-361.

31. Gambarotta G, Boccaccio C, Giordano S, Ando M, Stella MC, Comoglio PM. Ets up-regulates MET transcription. Oncogene. 1996; 13: 1911-1917.

32. Boon EM, van der Neut R, van de Wetering M, Clevers H, Pals ST. Wnt signaling regulates expression of the receptor tyrosine kinase met in colorectal cancer. Cancer Res. 2002; 62: 5126-5128.

33. Migliore C, Martin V, Leoni VP, Restivo A, Atzori L, Petrelli A, Isella C, Zorcolo L, Sarotto I, Casula G, Comoglio PM, Columbano A, Giordano S. MiR-1 downregulation cooperates with MACC1 in promoting MET overexpression in human colon cancer. Clin Cancer Res. 2012; 18: 737-747.

34. Jung KH, Park BH, Hong SS. Progress in cancer therapy targeting c-Met signaling pathway. Arch Pharm Res. 2012; 35: 595-604.

35. Gherardi E, Birchmeier W, Birchmeier C, Vande Woude G. Targeting MET in cancer: rationale and progress. Nat Rev
Cancer. 2012; 12: 89-103.

36. Tsugawa K, Yonemura Y, Hirono Y, Fushida S, Kaji M, Miwa K, Miyazaki I, Yamamoto H. Amplification of the c-met, c-erbB-2 and epidermal growth factor receptor gene in human gastric cancers: correlation to clinical features. Oncology. 1998; 55: 475-481.

37. Lee J, Seo JW, Jun HJ, Ki CS, Park SH, Park YS, Lim HY, Choi MG, Bae JM, Sohn TS, Noh JH, Kim S, Jang $\mathrm{HL}$ et al. Impact of MET amplification on gastric cancer: possible roles as a novel prognostic marker and a potential therapeutic target. Oncol Rep. 2011; 25: 1517-1524.

38. Lennerz JK, Kwak EL, Ackerman A, Michael M, Fox SB, Bergethon K, Lauwers GY, Christensen JG, Wilner KD, Haber DA, Salgia R, Bang YJ, Clark JW et al. MET amplification identifies a small and aggressive subgroup of esophagogastric adenocarcinoma with evidence of responsiveness to crizotinib. J Clin Oncol. 2011; 29: 48034810 .

39. An X, Wang F, Shao Q, Wang FH, Wang ZQ, Wang ZQ, Chen C, Li C, Luo HY, Zhang DS, Xu RH, Li YH. MET amplification is not rare and predicts unfavorable clinical outcomes in patients with recurrent/metastatic gastric cancer after chemotherapy. Cancer. 2014; 120: 675-682.

40. Lee HE, Kim MA, Lee HS, Jung EJ, Yang HK, Lee BL, Bang YJ, Kim WH. MET in gastric carcinomas: comparison between protein expression and gene copy number and impact on clinical outcome. Br J Cancer. 2012; 107: 325 333.

41. Liu YJ, Shen D, Yin X, Gavine P, Zhang T, Su X, Zhan P, Xu Y, Lv J, Qian J, Liu C, Sun Y, Qian Z et al. HER2, MET and FGFR2 oncogenic driver alterations define distinct molecular segments for targeted therapies in gastric carcinoma. Br J Cancer. 2014; 110: 1169-1178.

42. Wang K, Lim HY, Shi S, Lee J, Deng S, Xie T, Zhu Z, Wang Y, Pocalyko D, Yang WJ, Rejto PA, Mao M, Park $\mathrm{CK}$ et al. Genomic landscape of copy number aberrations enables the identification of oncogenic drivers in hepatocellular carcinoma. Hepatology. 2013; 58: 706-717.

43. Kondo S, Ojima H, Tsuda H, Hashimoto J, Morizane C, Ikeda M, Ueno H, Tamura K, Shimada K, Kanai Y, Okusaka T. Clinical impact of c-Met expression and its gene amplification in hepatocellular carcinoma. Int J Clin Oncol. 2013; 18: 207-213.

44. Sun W, Song L, Ai T, Zhang Y, Gao Y, Cui J. Prognostic value of MET, cyclin D1 and MET gene copy number in non-small cell lung cancer. J Biomed Res. 2013; 27: 220230.

45. Go H, Jeon YK, Park HJ, Sung SW, Seo JW, Chung DH. High MET gene copy number leads to shorter survival in patients with non-small cell lung cancer. J Thorac Oncol. 2010; 5: 305-313.

46. Bean J, Brennan C, Shih JY, Riely G, Viale A, Wang L, Chitale D, Motoi N, Szoke J, Broderick S, Balak M, Chang WC, Yu CJ et al. MET amplification occurs with 
or without T790M mutations in EGFR mutant lung tumors with acquired resistance to gefitinib or erlotinib. Proc Natl Acad Sci U S A. 2007; 104: 20932-20937.

47. Turke AB, Zejnullahu K, Wu YL, Song Y, Dias-Santagata D, Lifshits E, Toschi L, Rogers A, Mok T, Sequist L, Lindeman NI, Murphy C, Akhavanfard S et al. Preexistence and clonal selection of MET amplification in EGFR mutant NSCLC. Cancer Cell. 2010; 17: 77-88.

48. Engelman JA, Zejnullahu K, Mitsudomi T, Song Y, Hyland C, Park JO, Lindeman N, Gale CM, Zhao X, Christensen J, Kosaka T, Holmes AJ, Rogers AM et al. MET amplification leads to gefitinib resistance in lung cancer by activating ERBB3 signaling. Science. 2007; 316: 1039-1043.

49. Lee JH, Han SU, Cho H, Jennings B, Gerrard B, Dean M, Schmidt L, Zbar B, Vande Woude GF. A novel germ line juxtamembrane Met mutation in human gastric cancer. Oncogene. 2000; 19: 4947-4953.

50. Seo JS, Ju YS, Lee WC, Shin JY, Lee JK, Bleazard T, Lee J, Jung YJ, Kim JO, Shin JY, Yu SB, Kim J, Lee ER et al. The transcriptional landscape and mutational profile of lung adenocarcinoma. Genome Res. 2012; 22: 2109-2119.

51. Okuda K, Sasaki H, Yukiue H, Yano M, Fujii Y. Met gene copy number predicts the prognosis for completely resected non-small cell lung cancer. Cancer Sci. 2008; 99: 22802285 .

52. Ludovini V, Bianconi F, Pistola L, Pistola V, Chiari R, Colella R, Bellezza G, Tofanetti FR, Siggillino A, Baldelli E, Flacco A, Giuffrida D, Sidoni A et al. Optimization of patient selection for EGFR-TKIs in advanced non-small cell lung cancer by combined analysis of KRAS, PIK3CA, MET, and non-sensitizing EGFR mutations. Cancer Chemother Pharmacol. 2012; 69: 1289-1299.

53. Nakajima M, Sawada H, Yamada Y, Watanabe A, Tatsumi M, Yamashita J, Matsuda M, Sakaguchi T, Hirao T, Nakano H. The prognostic significance of amplification and overexpression of c-met and c-erb B-2 in human gastric carcinomas. Cancer. 1999; 85: 1894-1902.

54. Janjigian YY, Tang LH, Coit DG, Kelsen DP, Francone TD, Weiser MR, Jhanwar SC, Shah MA. MET expression and amplification in patients with localized gastric cancer. Cancer Epidemiol Biomarkers Prev. 2011; 20: 1021-1027.

55. Ha SY, Lee J, Kang SY, Do IG, Ahn S, Park JO, Kang WK, Choi MG, Sohn TS, Bae JM, Kim S, Kim M, Kim S et al. MET overexpression assessed by new interpretation method predicts gene amplification and poor survival in advanced gastric carcinomas. Mod Pathol. 2013; 26: 1632-1641.

56. Onitsuka $\mathrm{T}$, Uramoto $\mathrm{H}$, Ono $\mathrm{K}$, Takenoyama $\mathrm{M}$, Hanagiri T, Oyama T, Izumi H, Kohno K, Yasumoto K. Comprehensive molecular analyses of lung adenocarcinoma with regard to the epidermal growth factor receptor, K-ras, MET, and hepatocyte growth factor status. J Thorac Oncol. 2010; 5: 591-596.

57. Masuya D, Huang C, Liu D, Nakashima T, Kameyama K, Haba R, Ueno M, Yokomise H. The tumour-stromal interaction between intratumoral c-Met and stromal hepatocyte growth factor associated with tumour growth and prognosis in non-small-cell lung cancer patients. Br J Cancer. 2004; 90: 1555-1562.

58. Olivero M, Rizzo M, Madeddu R, Casadio C, Pennacchietti S, Nicotra MR, Prat M, Maggi G, Arena N, Natali PG, Comoglio PM, Di Renzo MF. Overexpression and activation of hepatocyte growth factor/scatter factor in human non-small-cell lung carcinomas. Br J Cancer. 1996; 74: $1862-1868$.

59. Siegfried JM, Weissfeld LA, Singh-Kaw P, Weyant RJ, Testa JR, Landreneau RJ. Association of immunoreactive hepatocyte growth factor with poor survival in resectable non-small cell lung cancer. Cancer Res. 1997; 57: 433-439.

60. Park S, Choi YL, Sung CO, An J, Seo J, Ahn MJ, Ahn JS, Park K, Shin YK, Erkin OC, Song K, Kim J, Shim YM et al. High MET copy number and MET overexpression: poor outcome in non-small cell lung cancer patients. Histol Histopathol. 2012; 27: 197-207.

61. Ueki T, Fujimoto J, Suzuki T, Yamamoto H, Okamoto E. Expression of hepatocyte growth factor and its receptor c-met proto-oncogene in hepatocellular carcinoma. Hepatology. 1997; 25: 862-866.

62. Kiss A, Wang NJ, Xie JP, Thorgeirsson SS. Analysis of transforming growth factor (TGF)-alpha/epidermal growth factor receptor, hepatocyte growth Factor/c-met,TGF-beta receptor type II, and p53 expression in human hepatocellular carcinomas. Clin Cancer Res. 1997; 3: 1059-1066.

63. Tavian D, De Petro G, Benetti A, Portolani N, Giulini SM, Barlati S. u-PA and c-MET mRNA expression is coordinately enhanced while hepatocyte growth factor mRNA is down-regulated in human hepatocellular carcinoma. Int $\mathrm{J}$ Cancer. 2000; 87: 644-649.

64. Wu F, Wu L, Zheng S, Ding W, Teng L, Wang Z, Ma Z, Zhao W. The clinical value of hepatocyte growth factor and its receptor-c-met for liver cancer patients with hepatectomy. Dig Liver Dis. 2006; 38: 490-497.

65. Wang ZL, Liang $\mathrm{P}$, Dong BW, Yu XL, Yu de J. Prognostic factors and recurrence of small hepatocellular carcinoma after hepatic resection or microwave ablation: a retrospective study. J Gastrointest Surg. 2008; 12: 327-337.

66. Lutterbach B, Zeng Q, Davis LJ, Hatch H, Hang G, Kohl NE, Gibbs JB, Pan BS. Lung cancer cell lines harboring MET gene amplification are dependent on Met for growth and survival. Cancer Res. 2007; 67: 2081-2088.

67. Ma PC, Maulik G, Christensen J, Salgia R. c-Met: structure, functions and potential for therapeutic inhibition. Cancer Metastasis Rev. 2003; 22: 309-325.

68. Cui Y, Dai G, Re Y, Zhou F, Fan S, Sai Y, Gu Y, Yan J, Li J, Qing W, Su WG. A novel and selective c-Met inhibitor against subcutaneous xenograft and othotopic brain tumor models Cancer Res. 2011; 71(8 Suppl):Abstract nr 3612.

69. Gavine PR, Fan S, Fu H, Han L. Volitinib (HMPL504), a novel, selective and potent cMET inhibitor, is efficacious 
in primary tumor models of cMET-driven gastric cancer. Cancer Res. 2013; 73(8 Suppl):Abstract nr 928.

70. Zhou F, Ren Y, Cui Y, Chen H, Jiao LX, Dai GX, Fan SM, Sun J, Yu YJ, Sai Y, Gu Y, Qing WG, Su WG. Synergistic effect of c-Met inhibitor volitinib in combination with EGFR inhibitor Gefitnib on EGFR-TKI resistant NSCLC model HCC827C4R harboring acquired Met gene amplification. Cancer Res. 2013; 73(8 Suppl):Abstract nr 971.

71. D'Cruz C, Baran G, Ren Y, Adam A, Barry E. Targeting MET in preclinical models to support the clinical development of Volitinib in NSCLC. Cancer Res. 2014; 74(19 Suppl):Abstract nr 3114.

72. Gan H, Lickliter J, Millward M, Gu Y, Su W. First-inhuman phase I study of a selective c-Met inhibitor volitinib (HMP504/AZD6094) in patients with advanced solid tumors. J Clin Oncol. 2014; 32: 5s (suppl;abstr 11111).

73. Koblish HK, Liu X, Hall L, Qing WG, Zinda M, Su WG, Clark E. Preclinical in vivo characterization of INCB028060, a novel, potent and highly selective c-Met inhibitor. J Clin Oncol. 2008; 26: 15s (suppl;abstr 14561).

74. Liu X, Wang Q, Yang G, Marando C, Koblish HK, Hall LM, Fridman JS, Behshad E, Wynn R, Li Y, Boer J, Diamond $\mathrm{S}, \mathrm{He} \mathrm{C}$ et al. A novel kinase inhibitor, INCB28060, blocks c-MET-dependent signaling, neoplastic activities, and cross-talk with EGFR and HER-3. Clin Cancer Res. 2011; 17: 7127-7138.

75. Bang YJ, Su WC, Nam DH, Lim WT, Bauer TM, Brana I, Poon RT, Hong DS, Lin CC, Peng B, Zhang Y, Zhao S, Kumar A et al. Phase I study of the safety and efficacy of INC280 in patients with advanced MET-dependent solid tumors. J Clin Oncol. 2014; 32: 5s (suppl; abstr 2520).

76. Wu YL, Yang CH, Kim DW, Su WC, Ahn MJ, Lee DH, Vansteenkiste JF, Zhang L, Felip E, Peng B, Gong Y, Zhao S, Amagasaki T et al. Safety and efficacy of INC280 in combination with gefitinib (gef) in patients with EGFRmutated (mut), MET-positive NSCLC: A single-arm phase lb/1l study. J Clin Oncol. 2014; 32: 5s (suppl;abstr 8017).

77. Burgess TL, Sun J, Meyer S, Tsuruda TS, Sun J, Elliott G, Chen Q, Haniu M, Barron WF, Juan T, Zhang K, Coxon A, Kendall RL. Biochemical characterization of AMG 102: a neutralizing, fully human monoclonal antibody to human and nonhuman primate hepatocyte growth factor. Mol Cancer Ther. 2010; 9: 400-409.

78. Giordano S. Rilotumumab, a mAb against human hepatocyte growth factor for the treatment of cancer. Curr Opin Mol Ther. 2009; 11: 448-455.

79. Jun HT, Sun J, Rex K, Radinsky R, Kendall R, Coxon A, Burgess TL. AMG 102, a fully human anti-hepatocyte growth factor/scatter factor neutralizing antibody, enhances the efficacy of temozolomide or docetaxel in U-87 MG cells and xenografts. Clin Cancer Res. 2007; 13: 6735-6742.

80. Van Cutsem E, Eng C, Nowara E, Swieboda-Sadlej A, Tebbutt NC, Mitchell E, Davidenko I, Stephenson J,
Elez E, Prenen H, Deng H, Tang R, McCaffery I et al. Randomized phase Ib/II trial of rilotumumab or ganitumab with panitumumab versus panitumumab alone in patients with wild-type KRAS metastatic colorectal cancer. Clin Cancer Res. 2014; 20: 4240-4250.

81. Gordon MS, Sweeney CS, Mendelson DS, Eckhardt SG, Anderson A, Beaupre DM, Branstetter D, Burgess TL, Coxon A, Deng H, Kaplan-Lefko P, Leitch IM, Oliner KS et al. Safety, pharmacokinetics, and pharmacodynamics of AMG 102, a fully human hepatocyte growth factorneutralizing monoclonal antibody, in a first-in-human study of patients with advanced solid tumors. Clin Cancer Res. 2010; 16: 699-710.

82. Ryan CJ, Rosenthal M, Ng S, Alumkal J, Picus J, Gravis G, Fizazi K, Forget F, Machiels JP, Srinivas S, Zhu M, Tang $\mathrm{R}$, Oliner KS et al. Targeted MET inhibition in castrationresistant prostate cancer: a randomized phase II study and biomarker analysis with rilotumumab plus mitoxantrone and prednisone. Clin Cancer Res. 2013; 19: 215-224.

83. Wen PY, Schiff D, Cloughesy TF, Raizer JJ, Laterra J, Smitt M, Wolf M, Oliner KS, Anderson A, Zhu M, Loh E, Reardon DA. A phase II study evaluating the efficacy and safety of AMG 102 (rilotumumab) in patients with recurrent glioblastoma. Neuro Oncol. 2011; 13: 437-446.

84. Burgess T, Coxon A, Meyer S, Sun J, Rex K, Tsuruda T, Chen Q, Ho SY, Li L, Kaufman S, McDorman K, Cattley RC, Sun J et al. Fully human monoclonal antibodies to hepatocyte growth factor with therapeutic potential against hepatocyte growth factor/c-Met-dependent human tumors. Cancer Res. 2006; 66: 1721-1729.

85. Iveson $\mathrm{T}$, Donehower $\mathrm{RC}$, Davidenko I, Tjulandin $\mathrm{S}$, Deptala A, Harrison M, Nirni S, Lakshmaiah K, Thomas A, Jiang Y, Zhu M, Tang R, Anderson A et al. Rilotumumab in combination with epirubicin, cisplatin, and capecitabine as first-line treatment for gastric or oesophagogastric junction adenocarcinoma: an open-label, dose de-escalation phase $1 \mathrm{~b}$ study and a double-blind, randomised phase 2 study. Lancet Oncol. 2014; 15: 1007-1018.

86. David C, Niall C, Irina D, André M, Salah-Eddin A, David H, Sergei T, Evgeny G, Boguslawa K, Igor B, Mohamedtaki A, Anghel A, Mustapha A. Phase III, randomized, double-blind, multicenter, placebo $(\mathrm{P})$-controlled trial of rilotumumab $(\mathrm{R})$ plus epirubicin, cisplatin and capecitabine (ECX) as first-line therapy in patients (pts) with advanced MET-positive (pos) gastric or gastroesophageal junction (G/ GEJ) cancer: RILOMET-1 study. J Clin Oncol. 2015; 33: (suppl;abstr 4000).

87. Greenall SA, Adams TE, Johns TG. Incomplete target neutralization by the anti-cancer antibody rilotumumab. MAbs. 2016; 8: 246-252.

88. Martens T, Schmidt NO, Eckerich C, Fillbrandt R, Merchant M, Schwall R, Westphal M, Lamszus K. A novel one-armed anti-c-Met antibody inhibits glioblastoma growth in vivo. Clin Cancer Res. 2006; 12: 6144-6152.

89. Jin H, Yang R, Zheng Z, Romero M, Ross J, Bou-Reslan 
H, Carano RA, Kasman I, Mai E, Young J, Zha J, Zhang $\mathrm{Z}$, Ross $\mathrm{S}$ et al. MetMAb, the one-armed 5D5 anti-c-Met antibody, inhibits orthotopic pancreatic tumor growth and improves survival. Cancer Res. 2008; 68: 4360-4368.

90. Catenacci DV, Henderson L, Xiao SY, Patel P, Yauch RL, Hegde P, Zha J, Pandita A, Peterson A, Salgia R. Durable complete response of metastatic gastric cancer with antiMet therapy followed by resistance at recurrence. Cancer Discov. 2011; 1: 573-579.

91. Spigel DR, Ervin TJ, Ramlau RA, Daniel DB, Goldschmidt JH, Jr., Blumenschein GR, Jr., Krzakowski MJ, Robinet G, Godbert B, Barlesi F, Govindan R, Patel T, Orlov SV et al. Randomized phase II trial of Onartuzumab in combination with erlotinib in patients with advanced non-small-cell lung cancer. J Clin Oncol. 2013; 31: 4105-4114.

92. Spigel DR, Edelman MJ, O'Byrne K, Paz-Ares L, Shames $\mathrm{D}, \mathrm{Yu}$ W. Onartuzumab plus erlotinib versus erlotinib in previously treated stage IIIb and IV NSCLC: results from the pivotal phase III randomized, multicenter, placebocontrolled METLung (OAM4971g) global trial. J Clin Oncol. 2014; 32: 5s (suppl; abstr 8000).

93. Koeppen H, Yu W, Zha J, Pandita A, Penuel E, Rangell L, Raja R, Mohan S, Patel R, Desai R, Fu L, Do A, Parab V et al. Biomarker Analyses from a Placebo-Controlled Phase II Study Evaluating Erlotinib +/- Onartuzumab in Advanced Non-Small Cell Lung Cancer: MET Expression Levels Are Predictive of Patient Benefit. Clin Cancer Res. 2014; 20: 4488-4498.

94. Kolch W, Halasz M, Granovskaya M, Kholodenko BN. The dynamic control of signal transduction networks in cancer cells. Nat Rev Cancer. 2015; 15: 515-527.

95. Kuniyasu H, Yasui W, Kitadai Y, Yokozaki H, Ito H, Tahara E. Frequent amplification of the c-met gene in scirrhous type stomach cancer. Biochem Biophys Res Commun. 1992; 189: 227-232.

96. Graziano F, Galluccio N, Lorenzini P, Ruzzo A, Canestrari E, D'Emidio S, Catalano V, Sisti V, Ligorio C, Andreoni F, Rulli E, Di Oto E, Fiorentini G et al. Genetic activation of the MET pathway and prognosis of patients with high-risk, radically resected gastric cancer. J Clin Oncol. 2011; 29: 4789-4795.

97. Kawakami H, Okamoto I, Arao T, Okamoto W, Matsumoto K, Taniguchi H, Kuwata K, Yamaguchi H, Nishio K, Nakagawa K, Yamada Y. MET amplification as a potential therapeutic target in gastric cancer. Oncotarget. 2013; 4: 9-17. doi: 10.18632/oncotarget.718.

98. Graziano F, Catalano V, Lorenzini P, Giacomini E, Sarti D, Fiorentini G, De Nictolis M, Magnani M, Ruzzo A. Clinical impact of the HGF/MET pathway activation in patients with advanced gastric cancer treated with palliative chemotherapy. Pharmacogenomics J. 2014; 14: 418-423.

99. Huang TJ, Wang JY, Lin SR, Lian ST, Hsieh JS. Overexpression of the c-met protooncogene in human gastric carcinoma-correlation to clinical features. Acta
Oncol. 2001; 40: 638-643.

100. Beau-Faller M, Ruppert AM, Voegeli AC, Neuville A, Meyer N, Guerin E, Legrain M, Mennecier B, Wihlm JM, Massard G, Quoix E, Oudet P, Gaub MP. MET gene copy number in non-small cell lung cancer: molecular analysis in a targeted tyrosine kinase inhibitor naive cohort. J Thorac Oncol. 2008; 3: 331-339.

101. Cappuzzo F, Marchetti A, Skokan M, Rossi E, Gajapathy S, Felicioni L, Del Grammastro M, Sciarrotta MG, Buttitta F, Incarbone M, Toschi L, Finocchiaro G, Destro A et al. Increased MET gene copy number negatively affects survival of surgically resected non-small-cell lung cancer patients. J Clin Oncol. 2009; 27: 1667-1674.

102. Chen HJ, Mok TS, Chen ZH, Guo AL, Zhang XC, Su J, Wu YL. Clinicopathologic and molecular features of epidermal growth factor receptor T790M mutation and c-MET amplification in tyrosine kinase inhibitor-resistant Chinese non-small cell lung cancer. Pathol Oncol Res. 2009; 15: 651-658.

103. Ichimura E, Maeshima A, Nakajima T, Nakamura $T$. Expression of c-met/HGF receptor in human non-small cell lung carcinomas in vitro and in vivo and its prognostic significance. Jpn J Cancer Res. 1996; 87: 1063-1069.

104. Tokunou M, Niki T, Eguchi K, Iba S, Tsuda H, Yamada $\mathrm{T}$, Matsuno $\mathrm{Y}$, Kondo $\mathrm{H}$, Saitoh $\mathrm{Y}$, Imamura $\mathrm{H}$, Hirohashi S. c-MET expression in myofibroblasts: role in autocrine activation and prognostic significance in lung adenocarcinoma. Am J Pathol. 2001; 158: 1451-1463.

105. Tsao MS, Yang Y, Marcus A, Liu N, Mou L. Hepatocyte growth factor is predominantly expressed by the carcinoma cells in non-small-cell lung cancer. Hum Pathol. 2001; 32: 57-65.

106. Ma PC, Jagadeeswaran R, Jagadeesh S, Tretiakova MS, Nallasura V, Fox EA, Hansen M, Schaefer E, Naoki K, Lader A, Richards W, Sugarbaker D, Husain AN et al. Functional expression and mutations of c-Met and its therapeutic inhibition with SU11274 and small interfering RNA in non-small cell lung cancer. Cancer Res. 2005; 65: 1479-1488.

107. Nakamura Y, Niki T, Goto A, Morikawa T, Miyazawa K, Nakajima J, Fukayama M. c-Met activation in lung adenocarcinoma tissues: an immunohistochemical analysis. Cancer Sci. 2007; 98: 1006-1013.

108. Dziadziuszko R, Wynes MW, Singh S, Asuncion BR, Ranger-Moore J, Konopa K, Rzyman W, Szostakiewicz B, Jassem J, Hirsch FR. Correlation between MET gene copy number by silver in situ hybridization and protein expression by immunohistochemistry in non-small cell lung cancer. J Thorac Oncol. 2012; 7: 340-347.

109. Guichard C, Amaddeo G, Imbeaud S, Ladeiro Y, Pelletier L, Maad IB, Calderaro J, Bioulac-Sage P, Letexier M, Degos F, Clement B, Balabaud C, Chevet E et al. Integrated analysis of somatic mutations and focal copy-number changes identifies key genes and pathways in hepatocellular 
carcinoma. Nat Genet. 2012; 44: 694-698.

110. Selden C, Farnaud S, Ding SF, Habib N, Foster C, Hodgson HJ. Expression of hepatocyte growth factor mRNA, and c-met mRNA (hepatocyte growth factor receptor) in human liver tumours. J Hepatol. 1994; 21: 227-234.

111. Noguchi O, Enomoto N, Ikeda T, Kobayashi F, Marumo F, Sato C. Gene expressions of c-met and hepatocyte growth factor in chronic liver disease and hepatocellular carcinoma. J Hepatol. 1996; 24: 286-292.

112. D'Errico A, Fiorentino M, Ponzetto A, Daikuhara Y, Tsubouchi H, Brechot C, Scoazec JY, Grigioni WF. Liver hepatocyte growth factor does not always correlate with hepatocellular proliferation in human liver lesions: its specific receptor c-met does. Hepatology. 1996; 24: 60-64.

113. Osada S, Kanematsu M, Imai H, Goshima S, Sugiyama Y. Evaluation of extracellular signal regulated kinase expression and its relation to treatment of hepatocellular carcinoma. J Am Coll Surg. 2005; 201: 405-411.
114. Chau GY, Lui WY, Chi CW, Chau YP, Li AF, Kao HL, $\mathrm{Wu} \mathrm{CW}$. Significance of serum hepatocyte growth factor levels in patients with hepatocellular carcinoma undergoing hepatic resection. Eur J Surg Oncol. 2008; 34: 333-338.

115. Ke AW, Shi GM, Zhou J, Wu FZ, Ding ZB, Hu MY, Xu Y, Song ZJ, Wang ZJ, Wu JC, Bai DS, Li JC, Liu KD et al. Role of overexpression of CD151 and/or c-Met in predicting prognosis of hepatocellular carcinoma. Hepatology. 2009; 49: 491-503.

116. Chu JS, Ge FJ, Zhang B, Wang Y, Silvestris N, Liu LJ, Zhao CH, Lin L, Brunetti AE, Fu YL, Wang J, Paradiso $\mathrm{A}, \mathrm{Xu}$ JM. Expression and prognostic value of VEGFR-2, PDGFR-beta, and c-Met in advanced hepatocellular carcinoma. J Exp Clin Cancer Res. 2013; 32: 16. 